Marketing Mix and Brand Sales in Global Markets:

Examining the Contingent Role of Country-Market Characteristics

\author{
S. Cem Bahadir* \\ Assistant Professor of Marketing \\ Ozyegin University \\ Faculty of Business \\ Cekmekoy Kampusu \\ Nisantape Mah. Orman Sok. \\ 34794 Cekmekoy - Istanbul, Turkey \\ Phone: +(90) 216-564-9266 \\ Email: cem.bahadir@ozyegin.edu.tr \\ Sundar G. Bharadwaj \\ The Coca-Cola Company Chair Professor of Marketing \\ Terry School of Business \\ University of Georgia \\ Athens, GA 30306 \\ Phone: 706-542-5542 \\ Email: sundar@uga.edu \\ Rajendra K. Srivastava \\ Professor of Marketing \\ Singapore Management University \\ Lee Kong Chian School of Business \\ 50 Stamford Road \\ Singapore 178899 \\ Phone: $+(65)-6828-0591$ \\ Email: rajs@smu.edu.sg
}

Accepted for publication at Journal of International Business Studies

*Corresponding author. 


\title{
Marketing Mix and Brand Sales in Global Markets: Examining the Contingent Role of Country-Market Characteristics
}

\begin{abstract}
Marketing products globally is challenging due to the diverse nature of markets. We use market heterogeneity, unbranded competition, resource and infrastructure availability, and sociopolitical governance as country-market characteristics that distinguish between developed and emerging countries. We investigate their moderating role on the relationship between elements of the marketing mix and brand sales. We provide evidence, from a hierarchical linear model and a panel data set of brands from 14 emerging and developed markets that account for $62 \%$ of the global GDP, that country-market characteristics moderate the relationship between the complete set of marketing mix elements and brand sales performance asymmetrically. While distribution and price have the largest impact in emerging and developed countries respectively; product innovation and advertising have significantly larger impacts in emerging markets relative to developed countries. These finding highlights the importance of contingency view of marketing strategy in global markets.
\end{abstract}

Keywords: international marketing strategy, brand sales, performance, hierarchical linear model, emerging markets, marketing mix elasticity 


\section{INTRODUCTION}

Recent evidence from the revenues of US based multinational firms suggests that emerging markets are increasingly becoming a significant and even a majority of their sales and income growth. Major corporations expect this trend to continue (Wessel \& Greenberg, 2011). While multinational firms have experience in marketing products in developed markets, emerging markets tend to differ from developed markets on several fundamental dimensions such as governance, income, and infrastructure.

Consequently, the complexity of operating in multiple markets has intensified. A core complexity facing such firms is whether the differences between emerging and developed markets influence the impact of marketing mix elements on brand sales. Do such differences have similar effects on the elements of the marketing mix? If they do, why is that the case? By addressing these questions, we shed light on the nature and extent to which the brand sales returns to marketing mix resource allocation (e.g., distribution or advertising intensity) is moderated by country-market characteristics across developed and emerging markets.

International marketing scholars have generated significant insights on marketing products/services in multiple markets through two parallel and related streams of research (e.g., Cavusgil, Zou, \& Naidu, 1993; Farley, Hayes, \& Kopalle, 2004; Jain 1989; Townsend, Yeniyurt, \& Talay, 2009). The first stream of research has a long history and investigates the performance implications of standardization versus customization of marketing strategies across markets (e.g., Cavusgil \& Zou, 1994). Beginning with the conceptual debates on standardization (Levitt, 1983; Douglas \& Wind, 1987), in this line of research, scholars focus on adaptation/standardization of the content of the marketing strategy (e.g., should the marketing channel format be standardized across country-markets?) as opposed to the effectiveness of marketing mix deployment (e.g., how sensitive is the effectiveness of distribution intensity to country characteristics?). Also, the focus of the marketing strategy analysis is usually on the adaptation versus standardization of the overall marketing program as opposed to individual marketing mix elements ${ }^{1}$. The second stream of research addresses questions regarding the relationship between a subset of the elements of the marketing mix such as product (e.g., Roth, 1995), price (e.g., Erdem, Zhao, 
\& Valenzuela, 2004), or promotion (e.g., Farley et al., 2004) and brand performance. Furthermore, researchers in this stream are interested in understanding the demand elasticity of a specific individual marketing mix element such as price in each market in the sample and not on investigating the average/relative effects of marketing mix elements across markets (e.g., Chintagunta \& Desiraju, 2005; Erdem et al., 2004). A shared trait of these two streams of research is that samples either do not include emerging markets or at best they include few emerging markets. Tables $1 \mathrm{a}$ and $1 \mathrm{~b}$ provide a summary of the research.

---Insert Tables $1 \mathrm{a}$ and $1 \mathrm{~b}$ about here---

Against this backdrop, we attempt to bridge and extend these two parallel streams by investigating the relationship between the marketing mix deployment (advertising, product innovation, display, distribution, and price) and brand sales, and the moderating role of country-market characteristics on these relationships (see Figure 1) using a panel data set of brands marketed in developed and emerging markets.

\section{--- Insert Figure 1 about here ---}

This study makes the following contributions to the international business and marketing literatures. First, Griffith, Cavusgil, \& Xu (2008) identify the relationship between standardization or adaptation of business practices and firm performance as one of the primary future research themes in international business research. The rich literature on marketing strategy adaptation/standardization generated knowledge on management of marketing strategy content such as adaptation of product features, or promotions (Calantone, Cavusgil, Schmidt, \& Shin 2004; Hultman, Katsikeas, \& Robson, 2011). The gap in the literature is that the there is limited amount of insights into adaptation of marketing mix resource deployment across markets. For example, we do not know much about the country-market conditions under which allocating more resources to distribution is better nor do we know what the relative importance of distribution over the other marketing mix elements is across country markets. Our study fills this vital gap by providing insights into the brand sales effectiveness of deployment of all marketing mix elements with a sample of 14 developed and emerging markets (see Figure 2 for 
positioning of the study). Based on arguments about the significant differences between emerging and developed markets (e.g., Prahalad 2009; Sheth 2011), one would expect that the deployment of all the elements of the marketing mix would be sensitive to such differences, and all the marketing mix elements would require significant amount of adaptation of resource deployment. By studying a complete list of marketing mix elements, we find that the extent to which each marketing mix element requires resource allocation adaptation is different. These differences are stark depending on the marketing mix element. Consequently, investigating the effectiveness of only the aggregate marketing spending across emerging and developed markets without studying the deployment of specific marketing mix elements can be misleading as the sensitivity of the effectiveness of marketing mix elements to these differences varies significantly.

\section{--- Insert Figure 2 about here ---}

Second, we use a comprehensive framework that focuses on differences that are unique to emerging and developed markets. More specifically, we draw on Sheth (2011) to introduce four countrymarket characteristics, namely, market heterogeneity, unbranded competition, resource and infrastructure availability, and sociopolitical governance that distinguish between developed and emerging markets ${ }^{2}$ and serve as the moderators of the relationships among marketing mix elements and brand sales. Prior work in cross-country context that includes emerging markets predominantly use variables that are (a) mostly static and (b) fail to capture the unique differences between emerging and developed markets. For example, national culture, an often used moderator, is both static and fails distinguish to between emerging and developed markets (e.g., Hsieh, Pan, \& Setiono, 2004). In contrast, the cross-country differences in our framework are significantly more dynamic than traditional moderators used in extant research. As a consequence, the richer and dynamic distinctions, enable the identification of a more elaborate adaptation of marketing mix factors across the two broad sets of country markets than would have been possible with more static country level moderators.

Third, while the impact of country market differences between emerging and developed markets on brand sales is well-understood, there is a gap in the literature regarding the moderating role of these 
differences. Typically, in prior literature, the challenging characteristics of emerging markets such as poor infrastructure are discussed as impediments to achieving market objectives (e.g., Talukdar, Sudhir, \& Ainsle, 2002; Sheth 2011). However, the moderating role of such characteristics on marketing mix elements and brand performance is not systematically explored. As a theoretical contribution, we identify broad competing causal mechanisms that explain the moderating role of differences between emerging and developed markets on the relationship between marketing mix and brand sales. Our results suggest that the moderating effects of certain emerging market characteristics (e.g., market heterogeneity) on brand sales are in contrast to their main effects. In other words, an emerging market characteristic that has a negative direct effect on brand sales can have a positive moderating effect on the relationship between marketing mix elements and brand sales. This contribution informs market entry literature as well. Our finding suggests that the country-characteristics that may be seen as a deterrent to market entry (e.g. poor infrastructure) can have positive effects on the effectiveness of marketing mix elements as a result of lower level of competition.

Fourth, this study makes the following managerial contributions. We identify the relative impact of the marketing mix elements by investigating the brand sales elasticity of these elements. We find that in emerging markets, distribution has the highest brand sales elasticity. In developed markets, price has the highest brand sales elasticity. These findings highlight the importance of accessibility of products to different consumer populations in emerging markets. In many emerging markets, consumers are yet to try the products that have been marketed in developed markets. Thus, firms would benefit from allocating their marketing resources to distribution in order to generate higher sales volumes. In developed markets, price is the most critical marketing lever as a result of the competitive dynamics in these markets. Moreover, the sharp contrast with price elasticity being significantly lower, while advertising and innovation elasticities being higher in emerging countries, suggest that aspiration has stronger effect than affordability.

Fifth, we make the following empirical contributions to the literature. In contrast to prior literature that have typically explored less than the full set of marketing mix elements, we include the full 
set of marketing mix elements in our analysis. Inclusion of all elements of the marketing mix enables us to avoid bias that stem from omitted variables in the context of marketing mix and brand sales relationship (Bijmolt et al., 2005; Sethuraman, Tellis, \& Briesch, 2011). In addition, a key strength of the study is that international marketing theory is predominantly developed and empirically tested in the context of Western country-markets although the majority of the consumers in the world live in emerging markets (Burgess \& Steenkamp, 2006; Sheth, 2011). Thus, we know very little about the generalizability or contingencies of extant research findings across emerging countries. This study examines the moderating role of four major differences between seven emerging and seven developed markets accounting for $62 \%$ and $58.3 \%$ in terms of the global GDP and purchasing power parity respectively in $2013^{3}$; thus increasing the generalizability of the results.

\section{MODEL DEVELOPMENT}

Contingency theory states that the environment in which the firms operate govern their strategy and its impact on performance (Child, 1972; Miller \& Friesen, 1983). Empirical evidence suggests that the effectiveness of marketing strategies depends on the environment firms have to operate in a particular country (e.g., Katsikeas, Samiee, \& Theodosiou, 2006). The extant international marketing literature accounts for environmental differences by considering country-market characteristics such as culture and institutions (e.g., Talukdar, Sudhir, \& Ainsle, 2002; Tellis, Stremersch, \& Yin, 2003). The objective of this research is to investigate the moderating role of the differences between developed and emerging countries on the effectiveness of marketing mix elements. To do so, we draw on Sheth (2011)'s recent framework that distinguishes emerging markets from developed markets. He presents five characteristics of country markets that distinguish between developed and emerging markets, namely, market heterogeneity, sociopolitical governance, inadequate infrastructure, chronic shortage of resources, and unbranded competition. He argues that these factors call for a reexamination of marketing strategy for emerging markets. We draw on his framework and identify proxy measures of country market factors that reflect these characteristics as moderators upon which impact of the market mix on brand sales is 
contingent. Given the relative novelty of the framework and its specific focus on emerging markets, we take an exploratory approach to investigating the moderating role of five country-market characteristics. In other words, rather than presenting formal hypotheses, we present the arguments for different mechanisms through which these country-market characteristics may influence the marketing mix elements and rely on empirical results to determine which explanation holds.

We categorize the contingency variables into motivation and ability factors for firms and consumers following Merton's (1957) Motivation-Ability framework. This framework has demonstrated applicability to several areas including marketing (Maclnnis, Moorman, \& Jaworski, 1991; Boulding \& Staelin, 1995; Johnson \& Bharadwaj, 2005) and international business (Minbaeva et al., 2013; Morris, Davis \& Allen, 1994). The contingency factors impact the motivation of firms and customers by influencing the extent of new and incumbent competition and the willingness of the consumers to spend. Thus, the extent of competition and consumer spend could influence the impact of the marketing mix on brand sales. The contingency factors also impact the ability of firms by influencing the design and delivery of an effective marketing mix. We present the framework in Figure 3.

--- Insert Figure 3 about here ---

\section{Marketing Mix Elements and Brand Sales Performance}

Brand sales performance is measured using sales (in units) per capita as it reflects the market performance implication of marketing mix activities. Brand sales are extensively used as a proxy of market performance in prior literature to study the market performance of brands since it captures the consumers' purchase decisions (e.g., Sethuraman, Tellis, \& Briesch, 2011). The data set includes 14 different countries with heterogeneous population sizes. Population and overall consumption are highly correlated and so we divide the brand sales by the population in order to account for population differences across countries (e.g., Everdingen, Fok, \& Stremersch, 2009).

We include a complete set of marketing mix elements in our analysis to capture the full range of marketing activities related to brands in our sample. The marketing mix elements of interest are product 
(innovation intensity), promotion (advertising and display), place (distribution intensity) and price. The empirical evidence indicates that all of these marketing mix elements have a significant impact on brand sales (e.g., Bijmolt, Van Heerde, \& Pieters, 2005). We expect advertising, display, and distribution activity to have a positive, and price to have a negative impact on brand sales in line with prior literature (e.g., Bahadir, Bharadwaj, \& Parzen, 2009; Bezawada, Balachander, Kannan, \& Shankar, 2009).

We include product proxied by innovation intensity in our model because product innovation is one of the fundamental drivers of brand sales across product categories (e.g., Chandy \& Tellis, 2000). Product innovations lead to higher levels of market share and sales growth in the U.S. as well as in other countries (Bahadir, Bharadwaj, \& Parzen, 2009). Product innovation is also critical to reach new consumers in emerging markets as the existing offerings might be a poor fit for their needs. Firms that operate in a combination of developed and emerging markets introduce product innovations across all the markets and usually receive positive response from the consumers (Economist 2010).

\section{The Contingent Role of Country-Market Characteristics}

Market heterogeneity. Market heterogeneity refers to the variability in scale and consumption patterns among and across consumers in country markets. In the context of emerging markets, Sheth (2011) discusses the "bottom-of-the-pyramid" (p. 168) and the stark differences between urban and rural households. Furthermore, he states “..., market heterogeneity of emerging markets is less driven by diversity of needs, wants, and aspirations of consumers and more driven by resource constraints, such as wide range of haves and have-nots with respect to both income and net worth" (p.168). In order to measure market heterogeneity, we use (i) the proportion of households that earn less than $\$ 750$ dollars a year (about \$2 per day) and (ii) the percentage share of workforce in the agriculture sector ${ }^{4}$. Higher levels of market heterogeneity would be associated with a bigger "bottom of the pyramid" and higher rural population.

Market heterogeneity could play a moderating role on the marketing mix - brand sales relationship in two distinct ways, namely through consumer spending on branded products and better marketing mix strategy design and implementation. On the one hand, in countries where market 
heterogeneity is high, fewer consumers are able to afford to purchase market offerings (Chandrasekaran $\&$ Tellis, 2008). Citizens in poorer segments of the country are more likely to face a stricter budget constraint that will limit their ability to consume branded products (Dekimpe, Parker, \& Sarvary, 2000). This inability to buy branded products may exist even when the consumers are motivated by new products or made aware through advertising and in-store displays. Consequently, the budget constraining effect of market heterogeneity can be expected to attenuate the positive relationship between product, promotion and place on brand sales and enhance the effect of negative of price.

On the other hand, the market heterogeneity may enable firms to more effectively design and implement marketing mix strategies. The existence of attractive segments of wealthy customers may allow firms to design specific products, customize advertising messages and in-store displays and do so in a profitable manner. Recent empirical research finds that concentration of wealth in the hands of few, impacts the acceptance of new products more positively than when the country's wealth is spread around more equitably (Everdingen, Fok, \& Stremersch, 2009). Similarly, firms could develop affordable offerings targeted at less well-off segments and communicate the value through advertising and in-store displays. Customers finding such customized offering are more likely to adopt the new products and repurchase the product. Moreover, since such segments have offerings consistent with their ability to buy, targeted advertising and in-store displays may increase their willingness and motivation to purchase. The wealthier segment of the consumers would be willing to pay price premium for the new and existing products that are customized to their needs thus enhancing the impact of new product introductions on brand sales and mitigating the negative impact of price on brand sales (Golder \& Tellis, 2004) 5 .

Unbranded competition. Unbranded competition refers to country markets where the needs are fulfilled by local producers who sell unbranded products (Sheth, 2011). To capture this dimension we use per capita trademark applications in a country-market. Unbranded competition is likely to influence the effectiveness of marketing mix elements through two mechanisms, namely, consumer spending on branded products and branded competition. In emerging markets, 50-60\% of the market even for products such as jewelry, liquor, luggage, and appliances is served by unbranded producers. These conditions 
suggest that, in the presence of unbranded competition in a country-market, branded national level product manufacturers have to convince the consumers to switch from unbranded to branded products and to switch from local suppliers to organized retailers (e.g., supermarkets). However, in such a context, consumers do not have the motivation to pay attention to the marketing mix of branded products. Because many of the needs are fulfilled by the local suppliers, there is very little need for the consumers to go to a supermarket even when such a retailer is present as switching to a new retail format has significant costs to the consumers (Alba et al., 1997). Consequently, distributing the brand to more retailers or having more in-store displays would not have significant influence on the consumers' buying behavior. Furthermore, unbranded or generic products are sold at lower prices than branded products (Brekke, Holmas, \& Straume 2013; Grossman \& Shapiro, 1988). With a significant price disadvantage, it is very difficult for branded product producers to persuade consumers to try branded product with more advertising. In fact, even in the context of developed markets, consumers switch to private labels during economic contraction periods due to the price differential between private labels and national brands (Lamey et al., 2012). Therefore, the effectiveness of marketing mix elements is likely to be lower when the level of unbranded competition is higher. Also, the negative impact of price on brand sales is likely to be higher when the unbranded competition is higher.

On the other hand, the impact of marketing mix elements on brand sales would be stronger as a result of the lower level of branded competition. The market size is one of the fundamental factors that influence firms' decisions to enter markets (Mitra \& Golder, 2002). Since unbranded products are more common in emerging markets, the size and share of the branded product markets are smaller. Higher levels of unbranded competition and a smaller branded product market could deter new entrants coming into the market as they would have to invest substantial amount of resources to gain market share from (lower priced) incumbents and to convince unbranded product consumers to try their products. In a market where there are fewer players, incumbent firms can achieve market outcomes while spending lower marketing dollars (Sethuraman, Tellis, \& Briesch, 2011). For example, it would be possible to achieve the same level of share of voice with lower advertising or promotion dollars. Similarly, the 
success likelihood of new product introductions would be higher when there are fewer competing products in the market.

Resources and infrastructure. The availability of resources and the development of infrastructure in countries are highly correlated, and consequently, we combine these dimensions to address potential empirical concerns (e.g., multicollinearity) and to achieve conceptual parsimony. With respect to resources, Sheth (2011) discusses the shortage of power (electricity) and lack of skill-based labor which causes the production to be sporadic and inconsistent in emerging markets in contrast to developed markets. In terms of infrastructure, the author discusses the importance of physical roads, logistics, banking functions, and communication technology as factors that distinguishes emerging and developed markets. In order to capture differences in resources and infrastructure among country markets, we use power production, spending on higher education, railroads, roads, communication investment, and financial development as indicators.

The availability of resources and infrastructure may influence the effectiveness of marketing mix elements through two opposing mechanisms: (i) better marketing mix strategy design and implementation (ii) higher branded competition. First, the availability of resources and infrastructure enhances the overall productivity in an economy (Esfahani \& Ramirez, 2003; Röller \& Waverman, 2001). The presence of resources and infrastructure would enable firms to implement effective marketing mix strategies. For example, physical infrastructure would enable greater distribution intensity and better display strategies, while communication infrastructure would enable more effective advertising campaigns, and skilled labor would better enable the development and delivery of product innovation strategies. Moreover, resource availability and infrastructure access may help firms offer products at lower cost thus mitigating the negative effect of price on brand sales. Thus, the positive externality of resource and infrastructure availability could enhance the effect of product, promotion, and place on brand sales.

Second, availability of resources and infrastructure is likely to attract more firms to invest in such a country (e.g., Isobe, Makino, \& Montgomery, 2000; Fleisher, Li, \& Zhao, 2010). Similarly, research at a market level indicates that attractive markets draw new entrants to the market (Aaker \& Day, 1986). 
Such markets are likely to be appealing opportunities for manufacturers of branded products. Entry of more firms to a country-market results in more options both in and across product categories for consumers. In other words, consumers have more product options to choose from. Empirical findings suggest that consumers' choices in a particular product category are affected by marketing interventions in other product categories (e.g., Rusell \& Petersen, 2000). For example, price promotion in one product category reduces the consumers' purchase of other products (Leeflang \& Parreno-Selva, 2011). As a consequence of the negative externality of resource and infrastructure availability, higher levels of competition in and across product categories may reduce the impact of firm's marketing mix elements (product, promotion, and place) on brand sales and increase the price-sensitivity of consumers.

Sociopolitical governance. The role of sociopolitical institutions such as governmental and organizations is another factor that distinguishes developed and emerging country markets (Sheth, 2011). Developed markets tend to have superior sociopolitical governance than emerging markets. In order to capture the sociopolitical governance dimension, we use political stability, women's participation in national governance, and government spending. The sociopolitical governance is likely to influence effectiveness of marketing mix elements through two mechanisms, namely, consumer spending on branded products and higher branded competition.

The link between sociopolitical governance and consumer spending can be established through several channels. First, in a country where the stability of government is questionable, consumers are more likely to save for more potentially difficult times. Conversely, when there is political stability in a country, consumers would have greater confidence in their future so they would spend more (current consumption) instead of saving (for future consumption). Second, the participation in governance processes would enhance people's confidence in the system. The more influence the consumers perceive they have in the political process, the more confidence they are likely to have in the economic policies of their governments. Third, the countries which have greater quality of sociopolitical governance are more likely to have welfare systems and employment initiatives to support their citizens. Higher employment rate enhances consumers' confidence in the economy (Dunn \& Mirzaie, 2009). As the economics 
literature points out, when consumers have greater confidence in the economy, they consume more (Acemoglu \& Scott, 1994; Cotsomitis \& Kwan, 2006). Furthermore, empirical evidence suggests that consumers' responsiveness to marketing interventions such as advertising, change depending on how they perceive the economic conditions (Van Heerde et al., 2013). Consequently, the consumer confidence effect of socio economic governance suggests that the consumers' responsiveness to marketing interventions can be higher when they are in the consumption mode. More specifically, in case of better sociopolitical governance, the effect of product, place, and promotion on brand sales would be enhanced, and the impact of price on brand sales would be mitigated.

Good governance could also be associated with making country markets attractive for competitive entry of branded products. The importance of governance for attracting foreign direct investment (FDI) has long been discussed by international business scholars (e.g., Brewer, 1993; Stevens, 2000). Empirical findings suggest that the countries that have better governance systems attract higher levels of FDI (Globerman \& Shapiro, 2003; Loree \& Guisinger, 1995). Higher levels of FDI mean greater number of firms entering the country-market which leads to higher levels of competition across product categories. Higher quality governance also lowers the uncertainty and cost of doing business for domestic firms thus increasing their presence as well in markets. Higher levels of competition from both foreign and domestic firms may attenuate the effectiveness of the marketing mix elements and increase the pricesensitivity of consumers.

\section{METHODOLOGY}

\section{Data}

We test the model on data built from several sources. First, we worked with a market research company to compile data for brand sales and four of the five marketing mix elements (i.e., advertising, distribution, price and display). Second, we relied on the Product Launch Analytics database to collect data on product innovation across countries. Third, the Euromonitor and World Bank databases were the data sources for the country-market variables. The sample consists of 14 countries and includes emerging 
and developed markets. The emerging country-markets in the sample consist of Argentina, Brazil, Chile, China, India, Mexico, and Turkey, while the developed country-markets include Australia, Canada, France, Germany, Great Britain, Spain, and the U.S. The brands are marketed in following product categories: regular carbonated soft drinks, diet soft drinks, energy drinks, and juices. The sampling period is quarterly (3 months per quarter) and ranges between four and nine quarters. The length of the time series varies across countries, which leads to an unbalanced panel dataset. The product categories are frequently purchased thus, the four quarter time period reflects multiple purchase occasions.

\section{Measurement of Variables}

We use the natural log values of per capita brand sales in units as the measure of brand sales. The market research company conducts monthly surveys globally. In each country, 350 people are randomly sampled every month. Respondents answer a wide range of questions including their awareness of brandspecific advertising. We use the proportion of respondents who mentioned a brand's advertising in response to an unaided recall question as the measure of advertising awareness. The strength of the measure is that it relies on the consumers' unaided recall of the brands' ads instead of just exposures to ads because there is abundant empirical evidence that mere exposure to ads does not lead to recall of ads (e.g., Janiszewski, Noel, \& Sawyer, 2003).

The market research firm works with a wide network of retailers in each country-market. Display, distribution, price, and brand sales data are compiled on a monthly basis in each country-market. We aggregate the monthly data up to the quarterly level. Display activity is measured as the percentage of volume that is under display (e.g., in-shelf) in the store. The percent of stores where the brand is available serves as the measure of the distribution activity. We use quarterly average unit prices in stores converted to the U.S. dollars as the measure of brand prices. The total number of new products and SKUs introduced in a quarter serves as the proxy for the product innovation variable (Pauwels, 2004). The use of the number of SKUs as a proxy for product innovation is appropriate as Sorescu and Spanjol (2008) 
report that in the consumer packaged goods category, the product innovations are usually in the form of new flavors or new packaging.

We select proxies to capture the dimensions in Sheth (2011)'s conceptual framework. In order to capture the market heterogeneity, we use employment in agriculture sector and index of low-income households with annual income less than $\$ 750$ a year. The needs and wants of consumers living in urban versus rural areas are very different, especially in emerging markets (Viswanathan, Rosa, \& Ruth, 2010). Hence we use employment in agriculture sector to capture such differences. In order to capture the differences between high and low income consumers in emerging markets, we use the index of lowincome households with annual income less than $\$ 750$ a year (less than $\$ 2$ a day). We use this proxy because according to Sheth (2011) (p.168): "Heterogeneity of emerging markets is further compounded by large skewness (as much as $40 \%-50 \%$ ) toward what is referred to as the "bottom-of-the-pyramid" consumers, who are below the official poverty level of less than two dollars a day income". The lowincome household index is generated by setting the maximum value of percent of low-income households to 100 and adjusting the values for other countries accordingly.

We measure the unbranded competition by the number of trademark applications divided by population. In country markets where entrepreneurs choose to produce and market unbranded products, we should observe lower number of trademark applications compared to another country where entrepreneurs choose to market branded products. In countries where there is greater branded competition, entrepreneurs are more likely to register their brands and trademarks in order to protect their brands from competition. We use population to scale trademark applications to account for market size differences across countries. Finally, the variable is multiplied by -1 to capture unbranded competition in a country before the estimation of the model.

We combine resource availability and infrastructure dimension due to high correlation among the indicators of these constructs. According to Sheth (2011) (p.169), chronic shortage of power (electricity) and lack of skill-based labor tend to make production sporadic, inconsistent, and nonreplicable. To 
capture these dimensions, we use natural logarithm of per capita electricity production and natural log of spending per student in higher education. We specifically use spending-based proxy to capture skilledlabor variable to measure differences in the quality of the education systems. In his discussion of infrastructure, Sheth (2011) (p.169) discusses the importance of banking system along with physical roads and logistics in the infrastructure of a country: "It [inadequate infrastructure] also means lack of communication, information, and transaction technologies such as telephones and electricity". Based on this discussion, we use length of roads and railroads to measure the physical transportation and logistics infrastructure differences across countries. To address the communication differences, we use the natural $\log$ of per capita investment in communication. By using the aggregate investment proxy of communication, we are able to capture differences in terms of landlines, mobile phones, and internet access across countries. Finally, we use domestic credit to enterprises and households as percent of GDP as the proxy for financial development which is the established proxy for financial development in economics and finance literatures (Levine 1997) ${ }^{6}$.

Finally, we utilize three indicators, namely, political stability, government spending, and political participation to measure sociopolitical governance. Sheth (2011) focuses on the imperfect nature of competition in emerging markets due to governance characteristics. In order to capture the competitive implications of governance, we select proxies that are likely to capture the quality of governance in a country which would influence the foreign direct investment flow to that country. Foreign direct investment would move the nature of competition to a less imperfect state (e.g., Barrios, Gorg, \& Strobl, 2005; Kogut 1984). We complement Sheth (2011)'s discussion of sociopolitical governance with perspective of how sociopolitical governance can influence consumers' ability to purchase branded products. Consequently we include government spending and political participation indicators in the measure. Because none of the countries in are sample are governed by faith-based political systems, we do not include any proxies for it. Political stability refers to the perceptions of the likelihood that the government will be destabilized or overthrown by unconstitutional or violent means, including domestic violence and terrorism. Higher scores suggest better governance and higher political stability. In order to 
capture the participation in the political process, we use the percent of seats held by women in national parliaments. We use government spending to proxy the presence of government in economy. For market heterogeneity, resource and infrastructure availability, and sociopolitical governance we compute the averages of the indicators before we use them in the estimation. We present the measures and the descriptive statistics in Tables 2, 3a, and 3b.

--- Insert Tables 2, 3a, and 3b about here ---

To investigate whether these indicators distinguish between emerging and developed countries, we perform two t-tests. First, we compare the means of each indicator for emerging and developed markets (see Table 4). We find that the means are statistically different for each group. Second, we compare the means of the dimensions. For all four dimensions, we find that the means of dimensions for emerging and developed markets is statistically different (market heterogeneity: $t=-5.14, p<0.001$; unbranded competition: $\mathrm{t}=1.72, \mathrm{p}<0.1$; resources and infrastructure: $\mathrm{t}=6.99, \mathrm{p}<0.001$; sociopolitical governance: $\mathrm{t}=4.99, \mathrm{p}<0.001)$.

\section{--- Insert Table 4 about here ---}

\section{Model Specification and Estimation}

We use the following hierarchical linear model in testing the hypotheses:

\section{Level 1:}

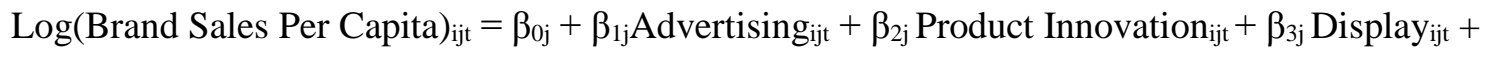

$$
\beta_{4 \mathrm{j}} \text { Distribution }_{\mathrm{ijt}}+\beta_{5 \mathrm{j}} \text { Price }_{\mathrm{ijt}}+\text { Time Dummies }+\mathrm{v}_{\mathrm{ij}}+\varepsilon_{\mathrm{ijt}}
$$

Level 2:

$$
\begin{gathered}
\beta_{0 \mathrm{j}}=\gamma_{00}+\gamma_{01} \text { Market Heterogeneity }_{\mathrm{jt}}+\gamma_{02} \text { Unbranded Competition }_{\mathrm{jt}}+\gamma_{03} \text { Resources Infrastructure }_{\mathrm{jt}}+ \\
\gamma_{04} \text { Sociopolitical Governance }_{\mathrm{jt}}+\mathrm{u}_{\mathrm{j}} \\
\beta_{1 \mathrm{j}}=\gamma_{10}+\gamma_{11} \text { Market Heterogeneity }_{\mathrm{jt}}+\gamma_{12} \text { Unbranded Competition }_{\mathrm{jt}}+\gamma_{13} \text { Resources Infrastructure }_{\mathrm{jt}}+ \\
\gamma_{14} \text { Sociopolitical Governance }_{\mathrm{jt}}+\mathrm{u}_{\mathrm{j}} \\
\beta_{2 \mathrm{j}}=\gamma_{20}+ \\
\gamma_{21} \text { Market Heterogeneity }_{\mathrm{jt}}+\gamma_{22} \text { Unbranded Competition }_{\mathrm{jt}}+\gamma_{23} \text { Resources Infrastructure }_{\mathrm{jt}}+ \\
\gamma_{24} \text { Sociopolitical Governance }_{\mathrm{jt}}+\mathrm{u}_{\mathrm{j}} \\
\beta_{3 \mathrm{j}}=\gamma_{30}+ \\
\gamma_{31} \text { Market Heterogeneity }_{\mathrm{jt}}+\gamma_{32} \text { Unbranded Competition }_{\mathrm{jt}}+\gamma_{33} \text { Resources Infrastructure }_{\mathrm{jt}}+ \\
\gamma_{34} \text { Sociopolitical Governance }_{\mathrm{jt}}+\mathrm{u}_{\mathrm{j}}
\end{gathered}
$$


$\beta_{4 \mathrm{j}}=\gamma_{40}+\gamma_{41}$ Market Heterogeneity $_{\mathrm{jt}}+\gamma_{42}$ Unbranded Competition $_{\mathrm{jt}}+\gamma_{43}$ Resources Infrastructure $_{\mathrm{jt}}+$ $\gamma_{44}$ Sociopolitical Governance $_{j t}+u_{j}$

$\beta_{5 \mathrm{j}}=\gamma_{50}+\gamma_{51}$ Market Heterogeneity $_{\mathrm{jt}}+\gamma_{52}$ Unbranded Competition $_{\mathrm{jt}}+\gamma_{53}$ Resources Infrastructure $_{\mathrm{jt}}+$ $\gamma_{54}$ Sociopolitical Governance $_{\mathrm{jt}}+\mathrm{u}_{\mathrm{j}}$

where $\mathrm{i}$ and $\mathrm{j}$ represent brands and countries respectively. We assume the brand-level error term $\mathrm{v}_{\mathrm{ij}}$ normally distributed with zero mean and variance $\sigma_{\mathrm{Brand}}{ }^{2}$. $\mathrm{u}_{\mathrm{j}}$ is the unique effect of country $\mathrm{j}$ on the intercept. As can be seen in equation 2, we also control for country-market characteristics as main effects. The random effect $u_{0 j t}$ is multivariate normally distributed over countries, each with an expected value of

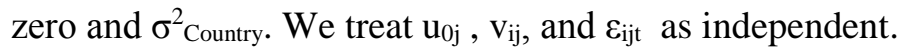

Model estimation. In our data, brands are nested within countries. Given the multilevel nature of the data, hierarchical linear modeling approach is appropriate (e.g., Peterson, Arregle, \& Martin, 2012). We mean-centered the Level 1 (marketing mix elements) variables within countries, and we grand-meancentered the Level 2 (country-market) variables (Raudenbush \& Bryk, 2002, Steenkamp \& Geyskens, 2006). We regressed advertising awareness, product innovation, display, and distribution on their lagged values along with lagged terms of brand sales. We find that lagged values of brand sales do not predict (i.e., Granger cause) these variables providing support for exogenous treatment of them in our model. We estimate the model with contemporaneous measure of price variable since the general pattern of results is similar to a model with endogenous treatment of the price variable. Using contemporaneous measure of price achieves greater power in the estimation of the model.

\section{RESULTS}

\section{Estimation Results}

The regression results are reported in Table 5. The overall model is significant (Wald $\chi^{2}($ d.f. $=36)$ $=503.53, \mathrm{p}<0.001)$. In order to test explanatory power of interaction terms, we first estimated the model with only main effects. This model has a $\mathrm{R}^{2}$ of 0.59 . The full model with country-market interactions has an $\mathrm{R}^{2}$ of 0.69 . The incremental $\mathrm{R}^{2}\left(\Delta \mathrm{R}^{2}\right)$ is significant at 0.01 level $\left(\mathrm{F}_{(20,746)}=11.97\right)$. 
Advertising $\left(\gamma_{10}=0.006, \mathrm{p}<0.01\right)$, product innovation $\gamma_{20}=0.024, \mathrm{p}<0.1$, display $\left(\gamma_{30}=0.019\right.$, $\mathrm{p}<0.01)$, distribution $\left(\gamma_{40}=0.016, \mathrm{p}<0.001\right)$ all have positive and significant impacts on brand sales. Price $\left(\gamma_{50}=-0.210, \mathrm{p}<0.001\right)$ as expected has a negative impact on brand sales. As expected, market heterogeneity has a negative impact on brand sales $\left(\gamma_{01}=-0.018, \mathrm{p}<0.001\right)$. Also, unbranded competition $\left(\gamma_{02}=-0.182, \mathrm{p}<0.1\right)$ has a negative impact on brand sales. Finally, resources and infrastructure $\left(\gamma_{03}=\right.$ 0.037, $\mathrm{p}<0.01)$, and sociopolitical governance $\left(\gamma_{04}=0.047, \mathrm{p}<0.05\right)$ have positive impact on brand sales.

--- Insert Table 5 about here ---

The level of market heterogeneity moderates the relationship between product innovation, display, distribution, price and brand sales. The impact of product innovation on brand sales is greater when the market heterogeneity is higher than when it is lower $\left(\gamma_{21}=0.003, \mathrm{p}<0.1\right)$. Similarly, the impact of display and distribution on brand sales is higher when the market heterogeneity is higher than when the market heterogeneity is lower $\left(\gamma_{31}=0.942 \times 10^{-3}, \mathrm{p}<0.1 ; \gamma_{41}=0.343 \times 10^{-3}, \mathrm{p}<0.05\right)$. The effect of price on brand sales is higher when the market heterogeneity is higher $\left(\gamma_{51}=-0.011, \mathrm{p}<0.001\right)$.

Unbranded competition moderates the relationship between two marketing mix elements, namely, product innovation, distribution and brand sales. The impact of innovation on brand sales is greater when unbranded competition is greater than when it is lower $\left(\gamma_{22}=0.047, \mathrm{p}<0.05\right)$. However, unbranded competition mitigates the impact of distribution on brand sales $\left(\gamma_{42}=-0.011, \mathrm{p}<0.05\right)$. Unbranded competition does not moderate the relationship between advertising, display, price, and brand sales.

The moderating role of resources and infrastructure on marketing mix elements is reflected in advertising, distribution, price and brand sales relationships. The impact of advertising on brand sales is lower when the level of resources and infrastructure is greater than when it is lower $\left(\gamma_{13}=-0.327 \times 10^{-3}\right.$, $\mathrm{p}<0.05)$. The effect of distribution on sales is lower when the level of resources and infrastructure is greater $\left(\gamma_{43}=-0.643 \times 10^{-3}, \mathrm{p}<0.01\right)$. Finally, higher level of resources and infrastructure enhances the effect of price on brand sales $\left(\gamma_{53}=-0.014, \mathrm{p}<0.01\right)$. Taken together, these findings provide support for the competition enhancing negative externality effect of resources and infrastructure on the effectiveness of marketing mix elements. 
The moderating role of sociopolitical governance on marketing mix elements is reflected in the impact of product innovation, display, distribution, and price on brand sales. The results pertaining to product innovation $\left(\gamma_{24}=0.009, \mathrm{p}<0.1\right)$, display $\left(\gamma_{34}=0.004, \mathrm{p}<0.1\right)$, distribution $\left(\gamma_{44}=0.001, \mathrm{p}<0.1\right)$, and price $\left(\gamma_{54}=0.017, \mathrm{p}<0.001\right)$ confirm the argument that responsiveness of consumers to marketing mix elements as a result of their motivation to consume more branded products. Confidence in governance mechanisms promotes confidence in future state of the economy which increases the propensity of consumers to spend more. Thus the consumer confidence effect serves as a stronger contingent effect than the competitive enhancement effect.

Robustness Checks. We also test the robustness of our results to the characterization of the nesting structure. We add another cross-sectional level where the countries are grouped into two categories defined as developed and emerging markets. The results are robust to this specification (see Table 6). Specifying the model with additional layer of emerging versus developed countries does not change results which suggest that four country-level variables capture all the variation across countries. If there was significant variance that was not explained by the country-level variables, we should have observed significant changes in the results when we estimate the model with three levels.

--- Insert Table 6 about here ---

\section{DISCUSSION}

\section{Summary of Findings}

The objective of this research is to integrate international marketing and marketing strategy literatures by testing a contingency framework examining the impact of country-market characteristics that distinguish between developed and emerging markets on the relationship between marketing mix elements and brand sales. The contingency model is tested on a complete set of marketing mix instruments, with panel data from 14 developed and emerging markets that account for $62 \%$ of the world's GDP in 2013, utilizing a hierarchical linear model. In contrast to some early research on international marketing strategy in developed country markets which suggests that marketing mix resource allocation can be standardized (e.g., Szymanski, Bharadwaj, \& Varadarajan, 1993), the results 
support the contingent role played by country-market characteristics and supports a nuanced view of the impact of the marketing mix variables in emerging versus developed markets. Overall, we find that the effectiveness of the marketing mix resource deployment depends on the differences between emerging and developed markets which supports the contingency approach proposed in the standardization and adaptation literature (e.g., Katsikeas, Samiee, \& Theodosiou, 2006).

The four emerging and developed market differences we study, moderate the relationship between marketing mix elements and brand sales through several broad mechanisms (Table 7). Market heterogeneity enhances the impact of product innovation, display and distribution on brand sales because it enables the firms to more effectively design and implement marketing mix strategies. Using these marketing mix elements, firms are able to identify and customize their offerings to the consumer segments that will respond to these marketing tools (e.g., higher income consumers in urban areas).

\section{--- Insert Table 7 about here---}

The differences between emerging and developed markets influence the effectiveness of marketing mix elements through their impact on the competitive dynamics. Unbranded competition, a trait that is more common in emerging markets, enhances the impact of product innovation on brand sales. When the unbranded competition is greater, the branded product markets are likely to be less attractive for firms to enter. Thus, there is lower competition in the branded product markets which enhances the impact of new product introductions by incumbents on brand sales. The results pertaining to resources and infrastructure, which are greater in developed markets, support the competition-enhancing (i.e., negative externality effect) role of resources and infrastructure for advertising, distribution, and price. Given the greater competition in these markets, the impact of price on brand sales is higher when the availability and the level of infrastructure are higher. The impact of advertising and distribution on brand sales is lower when the level of resource and infrastructure availability is higher. We performed a posthoc analysis to examine these relationships. As depicted in Figure 4, the advertising still increases brand sales when the level of resource and infrastructure availability is high but the lift is only $8 \%$. Similarly, 
the distribution leads to $33 \%$ in sales when the level of resource and infrastructure is high as opposed to $82 \%$ when it is low (Figure 5).

\section{--- Insert Figures 4 and 5 about here ---}

The third mechanism through which differences between developed and emerging markets influence the marketing mix elements and brand sales relationship is consumer spending on branded products. Developed markets have better sociopolitical governance in comparison to emerging markets which enhances the consumer spending on branded products as a result of the consumers' confidence in the political and economic system. This difference influences the effectiveness of four of the five marketing mix elements, namely, product innovation, display, distribution, and price. The impact of product innovation, display, distribution on brand sales is greater when the quality of sociopolitical governance is better. Also supporting the consumer spending argument, the impact of price on brand sales is lower when the sociopolitical governance is better as in developed markets. In effect this result provides micro level evidence to macro level development economic research that governance, institutions and political stability are critical for economic growth and development (Acemoglu \& Robinson, 2012).

Market heterogeneity enhances the impact of price on brand sales through the consumer spending mechanism. In markets where there's greater market heterogeneity, there's greater population with limited income which leads to lower spending on branded products and higher price sensitivity. Finally, unbranded competition mitigates the impact of distribution on brand sales. The presence of unbranded products reduces the consumers' motivation to purchase branded products and so the impact of availability of the branded products on brand sales is lower than when there is less unbranded competition.

\section{Implications for practicing managers}

We computed the elasticities of country-market characteristics to understand their relative impact on brand sales. Market heterogeneity, unbranded competition, resources and infrastructure, and sociopolitical governance elasticities are $-0.45,-0.02,0.15$, and 1.15 , respectively ${ }^{7}$ (Table 8). On average, 
sociopolitical governance and market heterogeneity have the greatest impact on brand sales. Marketing managers need to monitor whether governance mechanisms are improving in the country-market they are operating because sociopolitical governance has significant direct impact on brand sales as well as indirect impact on brand sales through the enhanced effectiveness of marketing mix elements. The impact of market heterogeneity on brand sales may be more difficult to manage. While it enhances the effectiveness of the marketing mix, the main effect of market heterogeneity on brand sales is negative. Given the positive interaction between product innovation, display, and distribution and market heterogeneity, managers would benefit from introducing new products at premium prices for the affluent segment of the market. In order to serve greater number of customers in emerging markets (where market heterogeneity is higher), introducing products at lower price points aimed at lower income segments is also necessary. Unilever's strategy of introducing new detergents in regular packaging for the affluent segments and introducing sachets for the less affluent segments can be seen as an example of such an approach.

--- Insert Table 8 about here---

Firms need to have certain skills to benefit from market heterogeneity since market heterogeneity has a direct negative impact on brand sales. The precursor to benefiting from market heterogeneity is effective segmentation of consumers in emerging markets. The research on international segmentation of consumers emphasizes the importance of segmenting markets based on consumer characteristics (e.g., Riefler, Diamantopoulos, \& Siguaw, 2012). In the context of emerging markets, firms would benefit from investing in collecting information about the consumers segments with respect to location (rural versus urban) and income levels (bottom-of-the pyramid versus high-income). The more accurately the firms can identify the consumer segments in emerging markets, the more effective they will be in overcoming the negative impact of market heterogeneity.

Our findings are also relevant to managers making marketing resource allocation decisions for firms across global markets. Using the results in Table 4, we computed the overall elasticities of marketing mix elements in order to understand the relative effectiveness of these tools. Distribution, 
price, display, advertising, and product innovation elasticities are $0.971,-0.894,0.115,0.057$, and 0.002, respectively. In the pooled sample of developed and emerging markets, distribution and price marketing mix elements have the greatest impact on brand sales. But this masks the heterogeneity across the two sets of country markets, as the magnitudes of the elasticities differ between emerging and developed markets (Table 9). In emerging markets, distribution has the greatest effect size and the price has the greatest effect size in developed markets. These results underscore the relative importance of making the products available in emerging markets and the relative importance of competitive dynamics in developed markets relative to emerging markets. It appears that consumers in emerging markets aspire for these products and hence the impact of price (affordability) is muted.

The findings also suggest that managers may benefit from fine-tuning their marketing strategies at a more nuanced level. While empirical generalizations at the level of a single country are difficult, our results suggest that in markets with strong unbranded competition (which has significant variance among emerging markets), product innovation might be the most effective vehicle. With regard to market heterogeneity (another factor that shows variance in emerging markets), innovation, display and distribution appear to be efficacious. The effect of price suggests that making acceptable (through innovation), products affordable (through price) and available (through distribution) seems critical in such markets.

--- Insert Table 9 about here---

In conclusion of managerial implications, it is important note that the findings that highlight the importance of adapting the various elements of the marketing mix relate to brand sales as a measure of brand performance. At the same time, we recognize that standardizing certain aspects of marketing mix strategies across markets could t lower marketing costs.

\section{Research Implications}

\section{Standardization versus adaptation of marketing resource allocation across emerging and}

developed markets. The empirical results on prior research on the performance implications of standardization/adaptation of the content of specific marketing mix elements are inconclusive. Katsikeas, 
Samiee, and Theodosiou (2006) find that product, promotion, and distribution misalignment has negative impact on performance and price strategy alignment does not influence performance. Lages, Jap, and Griffith (2008) report that product adaptation has a significant impact on performance. However, they do not find any significant link between promotion, pricing, distribution adaptation and performance. There are several differences between their study and ours: (i) they focus on the adaptation/standardization the content of marketing mix elements as opposed to deployment of these elements (ii) they use a composite performance measure (iii) their sample primarily consists of European countries. Based on a sample of emerging and developed markets, our results suggest that the impact of all the elements of the marketing mix on brand sales is influenced by at least one of the differentiating factors between emerging and developed markets. In other words, the deployment of all the marketing mix elements requires some level of adaptation across emerging and developed markets if the objective is to increase sales.

It is also important to note that the sensitivity of each marketing mix element's brand sales effectiveness to the breadth of differences between emerging and developed markets is asymmetric. For example, the impact of advertising on brand sales is influenced by only resource and infrastructure availability differences across emerging and developed markets whereas display (another promotional tool) effectiveness is impacted by market heterogeneity. The distribution effectiveness is influenced by all four country-market characteristics. These results underscore the importance of studying effectiveness of deployment of marketing mix elements in a disaggregate form. While studying the effectiveness of marketing spending across emerging and developed markets could generate some insights, it would not be appropriate to draw conclusions about the effectiveness of specific marketing mix elements based on overall marketing spending.

We use brand sales as the measure of brand performance which does not include cost implications of marketing mix strategies. Previous studies use composite performance measures that combine sales-based (topline), profit-based (bottomline), and in some cases customer satisfaction metrics (e.g., Hultman, Robson, \& Katsikeas, 2009). The fact that some studies do not find support for adaptation of the content of marketing mix strategies may be partially related to the use of composite performance 
measures. While we find support for adaptation of marketing mix elements in relation to the topline, i.e.,brand sales, we do not claim that standardization of some aspects of marketing mix strategy can not have any performance benefits. For example, standardization of advertising content across markets will be more cost-effective than designing different advertising content for different markets. In fact, our results underscore the importance of using both bottomline and topline performance metrics separately in order to understand the relationship between sales and costs of implementing particular marketing mix strategies.

Dual impact of difference between emerging and developed markets. We tested the moderating role of four country-market characteristics in the marketing mix elements and brand sales relationships. These country-market characteristics distinguish between emerging and developed countries. The results suggest that some of the country-market characteristics have dual impact on brand sales. For example, on average, market heterogeneity has a negative impact on sales but it enhances the effectiveness of three marketing mix elements (product innovation, display, and distribution). Similarly, resource and infrastructure availability, on average, has a positive impact on brand sales but it inhibits the effectiveness of two marketing mix elements (advertising, distribution). These country-market characteristics are also used as predictors of firms' decisions to enter emerging markets (e.g., Fleisher, Li, \& Zhao, 2010). In light of our results, it is possible that a firm enters a particular emerging market even when the market heterogeneity is high because of the potential to implement effective marketing mix strategies. To the extent that firms are forward-looking about the effectiveness of their marketing mix deployment (which would be the case for firms that have large marketing budgets), researchers who examine firms' entry decisions to emerging markets would benefit from considering the effectiveness impact of the countrymarket characteristics that they study as predictors of entry decisions to emerging markets.

Midrange Theory Development. The motivation-ability framework has been primarily applied in the context of main-effect and as static factors influencing desired outcomes (e.g., Grewal, Comer, \& Mehta, 2001; Boulding \& Staelin, 1995). This study provide both conceptual and empirical evidence for their role as moderating role in the relationship between marketing mix and sales performance across 
country markets. In presenting this contingency perspective and applying the framework in a dynamic and newer context, our study advances midrange theory building and broadens the applicability of the motivation-ability framework.

We find that the deployment of each marketing mix element requires adaptation albeit at different levels. Firms' ability and motivation to adapt the deployment of marketing mix elements according to changing country-market characteristics require further examination. On one hand, if the costs and time requirements of deployment of marketing mix elements are different, then firms are likely to adapt only certain elements of the marketing mix but not others. For example, it may be more difficult to adjust the distribution intensity of brands due to costs and time requirements of moving goods, and operational commitments to channel partners than to adjust advertising spending. Consequently, the effectiveness of the marketing mix elements that are less flexible is more likely to be influenced by the changes in the country-markets since the firms are not able to optimally adapt the deployment of these elements. On the other hand, if the pay-offs to adapting the costly marketing mix elements to the country-market conditions are large enough, firms should be motivated to adapt their marketing mix elements to the changing country conditions. Finally, it is possible to explore whether managers under-adapt due to behavioral reasons of resistance to change. Dow (2006) finds evidence of systematic under-adaptation in the content of marketing strategy. It is possible that managers engage in similar behavior in the context of marketing mix deployment. A process theory that incorporates costs, time requirements, and behavioral aspects of adaptation would provide insights into a firm's ability and motivation to adapt the deployment of marketing mix elements across markets.

\section{Limitations and Future Research Directions}

Our data set covers all the elements of the marketing mix and the sample includes developed and emerging markets. However, one of the limitations of the data set is that it covers maximum of nine quarters of data. While for the product categories in the sample it covers more than 30 purchase cycles, and thus is less of an issue, the long-term evolution of country-markets, both developed and emerging, is likely to influence consumers' preferences and firms' business practices. Over the long-run, business 
cycles have strong influence on the behavior of both businesses and consumers (Deleersnyder, Dekimpe, Steenkamp, \& Leeflang, 2009; Wan, Yiu, Hoskisson, \& Kim, 2008). However, we do not know much about the impact of business cycles on the relationship between marketing mix and brand sales. Future research could attempt at constructing country-market panels with longer time-series data (e.g., 10-40 years depending on the purchase frequency of the product) on brand sales and marketing mix variables. Such a data set would enable the researchers to study the impact of marketing mix elements on brand sales under various business-cycle regimes such as expansion and contraction across countries. The findings of such a study would provide valuable insights into global management of brands under different macroeconomic conditions.

We focus on sales implications of marketing resource allocation in emerging and developed markets. Our study offers unique insights about the impact of differences between developed and emerging markets on the relationship between marketing mix elements and brand sales. Future research could examine the factors that influence brand profitability in developed and emerging markets. Such a study would shed light on the impact of differences in marketing cost structures across developed and emerging markets. For example, labor cost of developing new products may be lower in emerging markets (e.g., India) if the product development can be primarily done in the host emerging market.

We find that country market factors that have been shown to influence market entry in one way in prior research, could influence the effectiveness of the marketing mix in a different way indicating that these decisions may not be independent. However, the research streams on market entry and marketing mix management have been developing in a parallel fashion. Future research would benefit from considering these decisions simultaneously and investigate whether firms' market entry decisions are purely driven by direct effects of country-market characteristics on expected performance or moderating role of country-market characteristics are included in the entry considerations.

We identify broad and opposing mechanisms through which differences between emerging and developed markets influence the impact of marketing mix elements on brand sales by using a sample of brands from consumer packaged goods categories. Future research could investigate whether the 
dominance of an explanatory mechanism depends on the product category characteristics. For example, in service industries (e.g., cell phone service providers) firms may be in a better position to benefit from market heterogeneity as a result of having direct customer information. Such access would enable the firms to design customized marketing mix strategies to the accurately identified segments in the market (e.g., low-income customers). If this argument holds, then the impact of market heterogeneity on brand sales would be greater in financial services sector than in CPG categories. Similarly, the impact of resources and infrastructure on the effectiveness of marketing mix deployment could work through effective design and implementation of marketing mix in durable product categories. Talented employees could add more value in the design and implementation of the marketing mix by offering more attractive and accessible options for financially constrained customers. In such a context, the competitive dynamics might be less important to the effectiveness of the marketing mix deployment. In other words, resources and infrastructure may enhance the impact of marketing mix elements on brands sales in consumer durable product categories as opposed to mitigating their impact on brand sales. 


\section{REFERENCES}

Aaker, D.A., \& Day, G. 1986. The perils of high-growth markets. Strategic Management Journal, 7(5): 409-421.

Acemoglu, D., \& Robinson, J. 2012. Why nations fail. New York, NY: Crown Business.

$\&$ Scott, A. 1994. Consumer confidence and rational expectations: are agents' beliefs consistent with the theory? The Economic Journal, 1-19.

Alba, J., Lynch, J., Weitz, B., Janiszewski, C., Lutz, R., Sawyer, A., \& Wood, S. 1997. Interactive home shopping: Consumer, retailer, and manufacturer incentives to participate in electronic markets. Journal of Marketing, 61(3): 38-53.

Bahadir, S. C., Bharadwaj, S. G., \& Parzen, M. 2009. A meta-analysis of the determinants of organic sales growth. International Journal of Research in Marketing, 26(4): 263-75.

Barrios, S., Gorg, H. \& Strobl, E. 2005. Foreign direct investment, competition and industrial development in the host country. European Economic Review, 49(7): 1761-1784.

Bezawada, R., Balachander, S., Kannan, P. K., \& Shankar. V. 2009. Cross-category effects of aisle and display placements: A spatial modeling approach and insights. Journal of Marketing, 73(3): 99-117.

Bijmolt, T., Van Heerde, H. J., \& Pieters, R. 2005. New empirical generalizations on the determinants of price elasticity. Journal of Marketing Research, 42(2): 141-156.

Boulding, W. and Staelin, R. 1995. Identifying Generalizable Effects of Strategic Actions on Firm Performance: The Case of Demand-Side Returns to R\&D Spending. Marketing Science 14 (3): G222G236.

Brekke, K. R., Holmas, T. H., \& Straume, O. R. 2013. Margins and market shares: Pharmacy incentives for generic substitution. European Economic Review, 61: 116-131.

Brewer, T. L. 1993. Government policies, market imperfections, and foreign direct investment. Journal of International Business Studies, 24(1): 101-120.

Boulding, W., \& Staelin, R. Identifying generalizable effects of strategic actions on firm performance: The case of demand-side returns to R\&D spending. Marketing Science, 14(3): G222-G236.

Burgess, S. M., \& Steenkamp, J.-B., E. M. 2006. Marketing renaissance: How research in emerging markets advances marketing science and practice. International Journal of Research in Marketing, 23(4): 337-356.

Calantone, R. J., Cavusgil, S. T., Schmidt, J . B., \& Shin, G.-C. 2004. Internationalization and the dynamics of product adaptation-an empirical investigation. Journal of Product Innovation Management. 21(3): 185-198.

Cameron, A. C., \& Trivedi, P. K. 2009. Microeconometrics using Stata. College Station, TX: Stata Press.

Cavusgil, S. T., \& Zou, S. 1994. Marketing strategy-performance relationship: An investigation of the empirical link in export market ventures. Journal of Marketing, 58(1): 1-21. 
Cavusgil, S. T., Zou, S., \& Naidu, G. M. 1993. Product and promotion adaptation in export ventures: An empirical investigation. Journal of International Business Studies, 24(3): 479-506.

Chandrasekaran, D., \& Tellis, G. 2008. Global takeoff of new products: Culture, wealth, or vanishing differences? Marketing Science, 27(5): 844-860.

Chandy, R., \& Tellis, G. 2000. The incumbent's curse? Incumbency, size, and radical product innovation. Journal of Marketing, 64(3): 1-17.

Child, J. 1972. Organizational structure, environment and performance: The role of strategic choice. Sociology, 6(1): 1-22.

Chintagunta, P., \& Desiraju, R. 2005. Strategic pricing and detailing behavior in international markets. Marketing Science, 24(1): 67-80.

Cotsomitis, J. A., \& Kwan, A. C. 2006. Can consumer confidence forecast household spending? Evidence from the European Commission business and consumer surveys. Southern Economic Journal, 597-610.

Dekimpe, M. G., Parker, P. M., \& Sarvary, M. 2000. Global diffusion of technological innovations: A coupled-hazard approach. Journal of Marketing Research, 37(1): 47-59.

Deleersnyder, B., Dekimpe, M. G., Steenkamp, J.-B., E. M., \& Leeflang, P. S. H. 2009. The role of natural culture in advertising's sensitivity to business cycles: An investigation across continents. Journal of Marketing Research, 46(5): 623-636.

Douglas, S., \& Wind, Y. 1987. The myth of globalization. Columbia Journal of World Business, 22(4): 19-29.

Dow, D. 2006. Adaptation and performance in foreign markets: Evidence of systematic under-adaptation. Journal of International Business Studies, 37(2): 212-26.

Dunn, L. F., \& Mirzaie, I. A. 2009. Turns in consumer confidence: An information advantage linked to manufacturing. Economic Inquiry, 44(2): 343-351.

Economist, 2010. The world turned upside down. 395 (8678): 3-6.

Erdem, T., Ying, Z., \& Valenzuela, A. 2004. Performance of store brands: A cross-country analysis of consumer store-brand preferences, perceptions, and risk. Journal of Marketing Research, 41(1): 86-100.

Esfehani, H. S., \& Ramirez, M. T. 2003. Institutions, infrastructure, and economic growth. Journal of Development Economics, 70(2): 443-477.

Everdingen, Y., Fok, D., \& Stremersch, S. 2009. Modeling global spillover of new product takeoff. Journal of Marketing Research, 46(5): 637-652.

Farley, J. U., Hayes, A. F., \& Kopalle, P. K. 2004. Choosing and upgrading financial services dealers in the US and UK. International Journal of Research in Marketing, 21(4): 359-375.

Fleisher, B., Li, H., \& Zhao, M. Q. 2010. Human capital, economic growth, and regional inequality in China. Journal of Development Economics, 92(2): 215-231. 
Globerman, S., \& Shapiro, D. 2003. Governance infrastructure and US foreign direct investment. Journal of International Business Studies, 34(1), 19-39.

Golder, P., \& Tellis, G. J. 2004. Growing, growing, gone: Cascades, diffusion, and turning points in the product life cycle. Marketing Science, 23(2): 207-218.

Grewal, R., Comer, J.M. \& Mehta, R.2001. An investigation into the antecedents of organizational participation in business-to-business electronic markets. Journal of Marketing 65(3): 17-33.

Griffith, D. A., Cavusgil S. T., Xu, S. 2008. Emerging themes in international business research. Journal of International Business Studies, 39(7): 1220-1235.

Grossman, G., \& Shapiro, C. 1988. Foreign counterfeiting of status goods. Quarterly Journal of Economics, 103(1):79-100.

Hsieh, M.-H., Pan, S.-L., \& Setiono, R. 2004. Product-, corporate-, and country-image dimensions and purchase behavior: A multicountry analysis. Journal of the Academy of Marketing Science, 32(3): 251-270.

Hultman, M., Katsikeas, C. S., \& Robson, M. J. 2011. Export promotion strategy and performance: The role of international experience. Journal of International Marketing, 19(4): 17-39.

Hultman, M., Robson, M. J., \& Katsikeas, C. S. 2009. Export product strategy fit and performance: An empirical investigation. Journal of International Marketing, 17(4): 1-23.

Isobe, T., Makino, S., \& Montgomery, D. B. 2000. Resource-commitment, entry timing, and market performance of foreign direct investments in emerging economies: The case of Japanese international joint ventures in China. Academy of Management Journal, 43(3): 468-484.

Jain, S. 1989. Standardization of international marketing strategy: Some research hypotheses. Journal of Marketing, 53(1): 70-79.

Janiszewski, C., Noel, H., \& Sawyer, A. G. 2003. A meta-analysis of the spacing in verbal learning: Implications for research on advertising repetition and consumer memory. Journal of Consumer Research, 30(1): 138-149.

Johnson, D. S. \& Bharadwaj, S.G. 2005. Digitization of selling activity and sales force performance: An empirical investigation. Journal of the Academy of Marketing Science 33(1): 3-18.

Katsikeas, D., Samiee, S., \& Theodosiou, M. 2006. Strategy fit and performance consequences of international marketing standardization. Strategic Management Journal. 27(9):867-890.

Kogut, B. 1984. Normative observations on the international value-added chain and strategic groups. Journal of International Business Studies, 15(2): 151-167.

Lages, L. F., Jap, S. D., \& Griffith, D. A. 2008. The role of past performance in export ventures: a shortterm reactive approach. Journal of International Business Studies, 39(2): 304-325.

Lamey, L., Deleersnyder, B., Steenkamp, J.-B. E. M., \& Dekimpe, M. G. 2012. The effect of businesscycle fluctuations on private-label share: What has marketing got to do with it? Journal of Marketing, 76(1): 1-19. 
Leeflang, P., \& Parreño-Selva, J. 2012. Cross-category demand effects of price promotions. Journal of the Academy of Marketing Science, 40(4): 572-586.

Levine, R. 1997. Financial development and economic growth: Views and agenda. Journal of Economic Literature, 35: 688-726.

Levitt, T. 1983. The globalization of markets. Harvard Business Review, 61(3): 92-101.

Loree, D. W., \& Guisinger, S. E. 1995. Policy and non-policy determinants of US equity foreign direct investment. Journal of International Business Studies, 26(2): 281-299.

MacInnis, D., Moorman, C. \& Jaworski, B. 1991. Enhancing and Measuring Consumers' Motivation, Opportunity and Ability to Process Brand Information. Journal of Consumer Research, 55(10): 32-53.

Merton, R. 1957. Social Theory and Social Structure. Free Press:Glencoe, IL.

Miller, D. \& Friesen, P. 1983. Strategy-making and environment: The third link. Strategic Management Journal, 4(3): 221-235.

Minbaeva, D., Torben Pedersen, B., Björkman, I., \& Fey,C.F. 2013. A retrospective on: MNC knowledge transfer, subsidiary absorptive capacity, and HRM. Journal of International Business Studies 45(1): 5262.

Mitra, D., \& Golder, P. 2002. Whose culture matters? Near-market knowledge and its impact on foreign market entry timing. Journal of Marketing Research, 39(3): 350-365.

Morris, M. H., Davis, D.L.\& Allen, J.W. 1994. Fostering corporate entrepreneurship: Cross-cultural comparisons of the importance of individualism versus collectivism. Journal of International Business Studies, 25(1): 65-89.

Pauwels, K. 2004. How dynamic consumer response, competitor response, company support, and company inertia shape long-term marketing effectiveness. Marketing Science, 23(4): 596-610.

Peterson, M. F., Arregle, J.-L., \& Martin, X. 2012. Multilevel models in international business research. Journal of International Business Studies, 43(5): 451-457.

Prahalad, C. K. 2009. The fortune at the bottom of the pyramid: Eradicating poverty through profits. Philedelphia, PA: Wharton School Publishing.

Raudenbush, S.W., \& Bryk, A. S. 2002. Hierarchical liner models: applications and data analysis methods. Thousand Oaks, CA: Sage Publication.

Riefler, P., Diamantopoulos, A., \& Siguaw, J. A. 2012. Cosmopolitan consumers as a target group for segmentation. Journal of International Business Studies, 43(3): 285-305.

Roth, M. S. 1995. The effects of culture and socioeconomics on the performance of global brand image strategies. Journal of Marketing Research, 32(2): 163-175.

Roth, M. S. 1992. Depth versus breadth strategies for global brand image management. Journal of Advertising, 21(2): 25-36. 
Röller, L.-H., \& Waverman, L. 2001. Telecommunications infrastructure and economic development: A simultaneous approach. American Economic Review, 91(4): 909-924.

Rusell, G., \& Petersen, A. 2000. Analysis of cross category dependence in market basket selection. Journal of Retailing, 76(3): 367-392.

Sethuraman, R., Tellis, G. J., \& Briesch, R. A. 2011. How well does advertising work? Generalizations from meta-analysis of brand advertising elasticities. Journal of Marketing Research, 48(3): 457-471.

Sheth, J. N. 2011. Impact of emerging markets on marketing: Rethinking existing perspectives and practices. Journal of Marketing, 75(4): 166-182.

Shoham, A. 1999. Bounded rationality, planning, standardization of international strategy, and export performance: a structural model examination. Journal of International Marketing, 7(2): 24-50.

Sorescu, A., \& Spanjol, J. 2008. Innovation's effect on firm value and risk: Insights from consumer packaged goods. Journal of Marketing, 72(2): 114-132.

Steenkamp, J.-B. E.M., Geyskens, I. 2006. How country characteristics affect the perceived value of web sites. Journal of Marketing, 70(3): 136-150.

Stevens, G. V. G. 2000. Politics, economics and investment: explaining plants and equipment spending by US direct investors in Argentina, Brazil, and Mexico. Journal of International Money and Finance, 19(2): 115-135.

Szymanski, D. M., Bharadwaj, S. G., \& Varadarajan, P. R. 1993. Standardization vs. adaptation of international marketing strategy: An empirical investigation. Journal of Marketing, 57(4): 1-17.

Talukdar, D., Sudhir, K., \& Ainslie, A. 2002. Investigating new product diffusion across product countries. Marketing Science, 21(1): 97-114.

Tellis, G. J., Stremersch, S., \& Yin, E. 2003. The international takeoff of new products: The role of economics, culture, and country innovativeness. Marketing Science, 22(2): 188-208.

Townsend, J. D., Yeniyurt, S., \& Talay, M. B. 2009. Getting to global: An evolutionary perspective of brand expansion in international markets. Journal of International Business Studies, 40(4): 539-558.

Van Heerde, H. J., Gijsenberg, M. J., Dekimpe, M. G., \& Steenkamp, J.-B. E.M. 2013. Price and advertising effectiveness over the business cycle. Journal of Marketing Research, 50(2): 177-193.

Viswanathan, M., Rosa, J. A., \& Ruth, J. A. 2010. Exchanges in marketing systems: The case of subsistence consumer-merchants in Chennai, India. Journal of Marketing, 74(3): 1-17.

Wan, W. P., Yiu, D. W., Hoskisson, R. E., \& Kim, H. 2008. The performance implications of relationship banking during macroeconomic expansion and contraction: A study of Japanese banks' social relationships and overseas expansion. Journal of International Business Studies, 39(3): 406-427.

Wessel, D., \& Greenberg, S. 2011. Big U.S. firms shift hiring abroad. Wall Street Journal, 257(90): B1B2. 


\section{NOTES}

${ }^{1}$ A notable exception is the study by Lages, Jap, and Griffith (2008). As shown in Table 1a, our study in addition to all the marketing mix elements in that study also has display. Moreover, this study has panel data and includes both developed and emerging market countries.

${ }^{2}$ While Sheth (2011) lists five traits that distinguish developed from emerging markets, we focus on four of them. We do so, because we find that two of the factors, namely the availability of resources and the development of infrastructure in countries are highly related so we combine these dimensions for conceptual parsimony and empirical reasons.

${ }^{3}$ http://data.worldbank.org/data-catalog/GDP-ranking-table and http://data.worldbank.org/datacatalog/GDP-PPP-based-table. PPP data was not available for Argentina and GDP\$ was used instead.

${ }^{4}$ It is important to note that as the size of the population that lives below the internationally recognized poverty level (\$2 a day) and the percent of population employed in agriculture sector increases, the income and the net worth divide in a country will be more severe. In other words, fewer number of people will disproportionately earn higher incomes and have much greater net worths compared to the 'bottomof-the-pyramid'. Therefore, these proxies capture the potential asymmetry in incomes and net worths that Sheth(2011) discusses.

${ }^{5}$ We acknowledge that the impact of better design and implementation of marketing strategy may be stronger/weaker in some product categories than others depending on consumption cycles associated with the product. We thank one of anonymous reviewers for pointing out this issue.

${ }^{6}$ We do not include GDP per capita as an indicator in these dimensions as it is an aggregate indicator that does not allow us to capture the difference between emerging and developed markets discussed by $\operatorname{Sheth}(2011)$.

${ }^{7}$ We follow the procedure by Cameron and Trivedi (2009) to compute the elasticities. Thus, we use the fully specified model in calculation of the elasticities. 
Table 1a Illustrative empirical cross-country studies on standardization/adaptation of the content of marketing mix and performance outcomes*

\begin{tabular}{|c|c|c|c|c|c|c|c|c|c|c|}
\hline \multirow[t]{2}{*}{ Study } & \multicolumn{6}{|c|}{ Inclusion of Marketing Mix Elements } & \multirow[t]{2}{*}{$\begin{array}{l}\text { Panel } \\
\text { Data }\end{array}$} & \multirow{2}{*}{$\begin{array}{l}\text { Resource } \\
\text { Deployment }\end{array}$} & \multirow[t]{2}{*}{$\begin{array}{l}\text { Simultaneous } \\
\text { test of } \\
\text { marketing } \\
\text { mix elements }\end{array}$} & \multirow{2}{*}{$\begin{array}{l}\text { Systematic } \\
\text { study of } \\
\text { emerging and } \\
\text { developed } \\
\text { markets }\end{array}$} \\
\hline & Product & Promotion & Advertising & Display & Distribution & Price & & & & \\
\hline $\begin{array}{l}\text { Calantone, } \\
\text { Cavusgil, Schmidt, } \\
\& \text { Shin (2004) }\end{array}$ & Yes & No & No & No & No & No & No & No & No & No \\
\hline $\begin{array}{l}\text { Hultman, } \\
\text { Katsikeas, \& } \\
\text { Robson (2011) }\end{array}$ & No & Yes & No & No & No & No & No & No & No & No \\
\hline $\begin{array}{l}\text { Hultman, Robson, } \\
\text { \& Katsikeas (2009) }\end{array}$ & Yes & No & No & No & No & No & No & No & No & No \\
\hline $\begin{array}{l}\text { Katiskeas, Samiee, } \\
\& \text { Thedosiou } \\
\text { (2006) }\end{array}$ & Yes & Yes & Yes & No & Yes & Yes & No & No & No & No \\
\hline $\begin{array}{l}\text { Lages, Jap, \& } \\
\text { Griffith (2008) }\end{array}$ & Yes & Yes & Yes & No & Yes & Yes & No & No & Yes & No \\
\hline $\begin{array}{l}\text { Shoham } \\
\text { (1999) }\end{array}$ & Yes & Yes & Yes & No & Yes & Yes & No & No & Yes & No \\
\hline THIS STUDY & Yes & Yes & Yes & Yes & Yes & Yes & Yes & Yes & Yes & Yes \\
\hline
\end{tabular}


Table 1b Illustrative empirical cross-country studies on deployment of marketing mix elements

\begin{tabular}{|c|c|c|c|c|c|c|c|c|}
\hline \multirow[t]{2}{*}{ Study } & \multicolumn{5}{|c|}{ Marketing Mix Elements } & \multirow{2}{*}{$\begin{array}{l}\text { Panel } \\
\text { Data }\end{array}$} & \multirow{2}{*}{$\begin{array}{l}\text { Number of } \\
\text { Emerging } \\
\text { Markets } \\
\text { Included }\end{array}$} & \multirow{2}{*}{$\begin{array}{c}\text { Systematic Study of } \\
\text { Differences between } \\
\text { Emerging and } \\
\text { Developed Markets }\end{array}$} \\
\hline & Advertising & Product & Display & Distribution & Price & & & \\
\hline $\begin{array}{l}\text { Chintagunta \& } \\
\text { Desiraju (2005) }\end{array}$ & No & Yes & Yes & No & Yes & Yes & 0 & No \\
\hline $\begin{array}{l}\text { Erdem, Zhao, \& } \\
\text { Valenzuela (2004) }\end{array}$ & No & No & No & No & Yes & Yes & 0 & No \\
\hline $\begin{array}{l}\text { Farley, Hayes, \& } \\
\text { Kopalle }(2004)^{*}\end{array}$ & Yes & Yes & No & No & Yes & No & 0 & No \\
\hline $\begin{array}{l}\text { Hsieh, Pan, \& } \\
\text { Setiono (2004) }\end{array}$ & No & Yes & No & No & No & No & 8 & No \\
\hline Roth (1992) & No & Yes & No & No & No & No & 5 & No \\
\hline Roth (1995) & No & Yes & No & No & No & No & 4 & No \\
\hline THIS STUDY & Yes & Yes & Yes & Yes & Yes & Yes & 7 & Yes \\
\hline
\end{tabular}

*Farley, Hayes, and Kopalle (2004) use a variable labeled as "promotion" in their model. We categorize it as advertising effort based on the measurement of the variable. 
Table 2 Variables, measures and descriptive statistics

\begin{tabular}{|c|c|c|c|}
\hline Variable & Measure & Mean & $\begin{array}{l}\text { Standard } \\
\text { Deviation }\end{array}$ \\
\hline Brand Sales per capita & $\begin{array}{l}\text { Sales in different package sizes are equalized to } \\
\text { common unit package size. Total sales figure is } \\
\text { divided by population. We use the natural log of } \\
\text { this variable in the analysis. }\end{array}$ & 0.0002 & 0.0003 \\
\hline Advertising & $\begin{array}{l}\text { Proportion of respondents who mentioned a } \\
\text { brand's advertising in response to an unaided } \\
\text { recall question. }\end{array}$ & $8.51 \%$ & 15.33 \\
\hline $\begin{array}{l}\text { Product } \\
\text { Innovation }\end{array}$ & $\begin{array}{l}\text { Total number of new products and SKUs } \\
\text { introduced in a quarter }\end{array}$ & 0.28 & 1.17 \\
\hline Display & Percent of units displayed across stores & $12.18 \%$ & 23.64 \\
\hline Distribution & Percent of stores where the brand is available. & $65.20 \%$ & 31.30 \\
\hline Price & $\begin{array}{l}\text { Quarterly average unit prices in stores converted } \\
\text { to U.S. dollars. }\end{array}$ & 5.72 & 4.04 \\
\hline $\begin{array}{l}\text { Market Heterogeneity: } \\
\text { Agriculture Employment }\end{array}$ & $\%$ of workforce employed in agriculture sector & 14.27 & 17.43 \\
\hline $\begin{array}{l}\text { Market Heterogeneity: } \\
\text { Low-income households }\end{array}$ & $\begin{array}{l}\text { Index of households with annual income less } \\
\text { than } \$ 750 \text { a year }\end{array}$ & 17.52 & 28.12 \\
\hline $\begin{array}{l}\text { Unbranded Competition: } \\
\text { Trademark Applications }\end{array}$ & $\begin{array}{l}\text { (Total number of trademark applications divided } \\
\text { by population)x } 10,000 \text { reverse coded }\end{array}$ & 10.79 & 6.96 \\
\hline $\begin{array}{l}\text { Resources and Infrastructure: } \\
\text { Power Availability }\end{array}$ & Natural log of per capita electricity production & 8.45 & 0.94 \\
\hline $\begin{array}{l}\text { Resources and Infrastructure: } \\
\text { Skilled Labor Availability }\end{array}$ & $\begin{array}{l}\text { Natural log of spending per student in higher } \\
\text { education }\end{array}$ & 8.79 & 0.78 \\
\hline $\begin{array}{l}\text { Resources and Infrastructure: } \\
\text { Railroads }\end{array}$ & [Length of railroads $(\mathrm{kms}) /$ Population]x100 & 0.07 & 0.07 \\
\hline $\begin{array}{l}\text { Resources and Infrastructure: } \\
\text { Roads }\end{array}$ & [Length of roads $(\mathrm{kms}) /$ Population] $\mathrm{x} 100$ & 1.42 & 1.37 \\
\hline $\begin{array}{l}\text { Resources and Infrastructure: } \\
\text { Communication Infrastructure }\end{array}$ & $\begin{array}{l}\text { Natural log of per capita investment in } \\
\text { communication }\end{array}$ & 4.38 & 1.32 \\
\hline $\begin{array}{l}\text { Resources and Infrastructure: } \\
\text { Financial Development }\end{array}$ & $\begin{array}{l}\text { Domestic credit to enterprises and households } \\
\text { as \% of GDP }\end{array}$ & $93.11 \%$ & 56.17 \\
\hline $\begin{array}{l}\text { Sociopolitical Governance: } \\
\text { Political Stability }\end{array}$ & $\begin{array}{l}\text { The index of the perceptions of the likelihood } \\
\text { that the government will be destabilized or } \\
\text { overthrown by unconstitutional or violent } \\
\text { means, including domestic violence and } \\
\text { terrorism (Range: }-2.5 \text { and } 2.5 \text { ) }\end{array}$ & 0.13 & 0.68 \\
\hline $\begin{array}{l}\text { Sociopolitical Governance: } \\
\text { Government Spending }\end{array}$ & Government final expenditure as \% of GDP & 16.12 & 4.07 \\
\hline $\begin{array}{l}\text { Sociopolitical Goveranance: } \\
\text { Political Participation }\end{array}$ & $\begin{array}{l}\% \text { of seats held by women in national } \\
\text { parliament }\end{array}$ & 19.08 & 8.73 \\
\hline \multicolumn{4}{|c|}{ Sample: 104 Brands, Time:4 to 9 quarters } \\
\hline
\end{tabular}


Table 3a Correlations table for main model variables

\begin{tabular}{|c|c|c|c|c|c|c|c|c|c|}
\hline \multirow{2}{*}{\multicolumn{10}{|c|}{ [1] Brand Sales }} \\
\hline & & & & & & & & & \\
\hline [2] Advertising & 0.42 & & & & & & & & \\
\hline [3] Product Innovation & 0.15 & 0.19 & & & & & & & \\
\hline [4] Display & 0.26 & -0.02 & 0.15 & & & & & & \\
\hline [5] Distribution & 0.37 & 0.09 & 0.03 & 0.50 & & & & & \\
\hline [6] Price & 0.03 & -0.07 & -0.04 & -0.10 & -0.01 & & & & \\
\hline [7] Market Heterogeneity & -0.42 & 0.10 & -0.06 & -0.18 & -0.24 & -0.29 & & & \\
\hline [8] Unbranded Competition & -0.34 & 0.07 & 0.03 & 0.08 & 0.34 & -0.09 & 0.42 & & \\
\hline [9] Resources \& Infrastructure & 0.19 & -0.14 & 0.20 & 0.41 & 0.19 & 0.18 & 0.39 & -0.04 & \\
\hline [10] Sociopolitical Governance & 0.20 & -0.06 & -0.00 & -0.18 & -0.16 & 0.42 & 0.38 & -0.36 & 0.40 \\
\hline
\end{tabular}

Table 3b Correlations table for country-level indicators

\begin{tabular}{|c|c|c|c|c|c|c|c|c|c|c|c|}
\hline \multirow{2}{*}{\multicolumn{12}{|c|}{ [1] Low income households }} \\
\hline & & & & & & & & & & & \\
\hline [2] Agricultural employment & 0.60 & & & & & & & & & & \\
\hline [3] Unbranded competition & 0.36 & 0.55 & & & & & & & & & \\
\hline [4] Railroads & -0.31 & -0.50 & -0.60 & & & & & & & & \\
\hline [5] Roads & -0.36 & -0.48 & -0.51 & 0.94 & & & & & & & \\
\hline [6] Communication infrastructure & -0.40 & -0.68 & -0.36 & 0.52 & 0.66 & & & & & & \\
\hline [7] Power availability & -0.56 & -0.83 & -0.44 & 0.69 & 0.78 & 0.85 & & & & & \\
\hline [8] Financial development & -0.18 & -0.41 & -0.03 & 0.39 & 0.52 & 0.77 & 0.72 & & & & \\
\hline [9] Skilled labor availability & -0.47 & -0.67 & -0.19 & 0.52 & 0.63 & 0.84 & 0.89 & 0.80 & & & \\
\hline [10] Political participation & -0.02 & -0.46 & -0.41 & 0.28 & 0.18 & 0.31 & 0.30 & 0.24 & 0.20 & & \\
\hline [11] Government spending & -0.28 & -0.53 & -0.07 & 0.28 & 0.44 & 0.70 & 0.69 & 0.58 & 0.61 & 0.17 & \\
\hline [12] Political stability & -0.48 & -0.73 & -0.56 & 0.59 & 0.59 & 0.77 & 0.77 & 0.52 & 0.76 & 0.35 & 0.56 \\
\hline
\end{tabular}

$* \rho>0.34$ are at 0.05 level. 
Table 4 Comparison of country-market indicators ${ }^{\mathrm{a}, \mathrm{b}}$

\begin{tabular}{lcc}
\hline Indicators & $\begin{array}{c}\text { Emerging } \\
\text { Countries }\end{array}$ & $\begin{array}{c}\text { Developed } \\
\text { Countries }\end{array}$ \\
\hline Market Heterogeneity & & \\
Agriculture Employment & 27.98 & 3.18 \\
& $(18.40)$ & $(1.45)$ \\
Low-income Households & 34.87 & 3.47 \\
Unbranded Competition & $(35.02)$ & $(4.33)$ \\
Trademark applications per capita & & \\
& 8.69 & 12.50 \\
Resources \& Infrastructure & $(7.25)$ & $(6.4)$ \\
Power availability per capita & & \\
& 7.53 & 9.19 \\
Skilled Labor per capita & $(0.48)$ & $(0.39)$ \\
& 8.12 & 9.34 \\
Railroads & $(0.57)$ & $(0.39)$ \\
& 0.03 & 0.10 \\
Roads & $(0.02)$ & $(0.08)$ \\
& 0.46 & 2.20 \\
Communication Infrastructure & $(0.17)$ & $(1.41)$ \\
& 3.13 & 5.39 \\
Financial Development & $(0.83)$ & $(0.49)$ \\
Sociopolitical Governance & 47.18 & 130.29 \\
Political Stability & $(42.12)$ & $(34.24)$ \\
Government Spending & & \\
& -0.35 & 0.51 \\
Political Participation & $(0.66)$ & $(0.40)$ \\
& $12.72 \%$ & $19 \%$ \\
STandar & $(2.14)$ & $(2.47)$ \\
& $15.54 \%$ & $21.94 \%$ \\
& $(8.97)$ & $(7.58)$ \\
\hline
\end{tabular}

${ }^{\text {a }}$ Standard deviations are reported in parentheses.

$\mathrm{b}$ The means of all indicators are significantly different for emerging and developed markets at $\mathrm{p}<0.05$. 
Table 5 Hierarchical linear model estimation results $(\mathrm{n}=783)$

\begin{tabular}{|c|c|c|c|c|}
\hline Independent Variables ${ }^{\mathrm{a}}$ & Expected Sign & Estimate & Std.Error & Sig. \\
\hline Intercept & & -9.454 & 0.285 & $* * *$ \\
\hline \multicolumn{5}{|l|}{ Marketing Mix } \\
\hline Advertising & + & 0.006 & 0.002 & $* *$ \\
\hline Product Innovation & + & 0.024 & 0.013 & $\dagger$ \\
\hline Display & + & 0.019 & 0.006 & $* *$ \\
\hline Distribution & + & 0.016 & 0.002 & $* * *$ \\
\hline Price & - & -0.210 & 0.029 & $* * *$ \\
\hline \multicolumn{5}{|c|}{ Country-Market Characteristics } \\
\hline Market Heterogeneity & - & -0.018 & 0.004 & $* * *$ \\
\hline Unbranded Competition & - & -0.182 & 0.111 & $\dagger$ \\
\hline Resources \& Infrastructure & + & 0.037 & 0.018 & $* *$ \\
\hline Sociopolitical Governance & + & 0.047 & 0.018 & $*$ \\
\hline \multicolumn{5}{|c|}{ Market Heterogeneity Interactions } \\
\hline Advertising $^{\mathrm{b}}$ & & -0.065 & 0.121 & \\
\hline Product Innovation & & 0.003 & 0.001 & $\dagger$ \\
\hline Display $^{\mathrm{b}}$ & & 0.942 & 0.533 & $\dagger$ \\
\hline Distribution $^{\mathrm{b}}$ & & 0.343 & 0.119 & $* *$ \\
\hline Price & & -0.011 & 0.002 & $* * *$ \\
\hline \multicolumn{5}{|c|}{ Unbranded Competition Interactions } \\
\hline Advertising & & -0.001 & 0.004 & \\
\hline Product Innovation & & 0.047 & 0.022 & $*$ \\
\hline Display & & -0.003 & 0.011 & \\
\hline Distribution & & -0.011 & 0.005 & $*$ \\
\hline Price & & -0.059 & 0.038 & \\
\hline \multicolumn{5}{|c|}{ Resources \& Infrastructure Interactions } \\
\hline Advertising $^{\mathrm{b}}$ & & -0.327 & 0.141 & $*$ \\
\hline Product Innovation $^{\mathrm{b}}$ & & 0.458 & 1.531 & \\
\hline Display $^{b}$ & & -0.113 & 0.396 & \\
\hline Distribution $^{\mathrm{b}}$ & & -0.643 & 0.219 & $* *$ \\
\hline Price & & -0.014 & 0.005 & $* *$ \\
\hline \multicolumn{5}{|c|}{ Sociopolitical Governance Interactions } \\
\hline Advertising & & -0.001 & 0.001 & \\
\hline Product Innovation & & 0.009 & 0.005 & $\dagger$ \\
\hline Display & & 0.004 & 0.002 & $\dagger$ \\
\hline Distribution & & 0.001 & 0.000 & $\dagger$ \\
\hline Price & & 0.017 & 0.004 & $* * *$ \\
\hline
\end{tabular}

Number of countries (\# of brands) 14 (104)

$* * * \mathrm{p}<0.001, * * \mathrm{p}<0.01, * \mathrm{p}<0.05, \dagger \mathrm{p}<0.1$.

a Time dummy variables' coefficient estimates are excluded for ease of presentation.

b The coefficient estimates of these variables are multiplied by $10^{3}$ for ease of exposition 
Table 6 Robustness check - emerging vs. developed market designation as an additional level ( $\mathrm{n}=783$ )

\begin{tabular}{|c|c|c|c|c|}
\hline Independent Variables $^{\mathrm{a}}$ & Expected Sign & Estimate & Std.Error & Sig. \\
\hline Intercept & & -9.452 & 0.301 & **** \\
\hline \multicolumn{5}{|l|}{ Marketing Mix } \\
\hline Advertising & + & 0.006 & 0.002 & $* *$ \\
\hline Product Innovation & + & 0.024 & 0.013 & $\dagger$ \\
\hline Display & + & 0.019 & 0.006 & $* *$ \\
\hline Distribution & + & 0.016 & 0.002 & $* * *$ \\
\hline Price & - & -0.211 & 0.029 & $* * *$ \\
\hline \multicolumn{5}{|c|}{ Country-Market Characteristics } \\
\hline Market Heterogeneity & - & -0.018 & 0.004 & $* * *$ \\
\hline Unbranded Competition & - & -0.183 & 0.111 & $\dagger$ \\
\hline Resources \& Infrastructure & + & 0.038 & 0.018 & $* *$ \\
\hline Sociopolitical Governance & + & 0.047 & 0.018 & $*$ \\
\hline \multicolumn{5}{|c|}{ Market Heterogeneity Interactions } \\
\hline Advertising $^{\mathrm{b}}$ & & -0.066 & 0.121 & \\
\hline Product Innovation & & 0.003 & 0.001 & $\dagger$ \\
\hline Display $^{\mathrm{b}}$ & & 0.942 & 0.534 & $\dagger$ \\
\hline Distribution $^{\mathrm{b}}$ & & 0.345 & 0.119 & $* *$ \\
\hline Price & & -0.011 & 0.002 & $* * *$ \\
\hline \multicolumn{5}{|c|}{ Unbranded Competition Interactions } \\
\hline Advertising & & -0.001 & 0.004 & \\
\hline Product Innovation & & 0.047 & 0.022 & $*$ \\
\hline Display & & -0.003 & 0.011 & \\
\hline Distribution & & -0.011 & 0.005 & $*$ \\
\hline Price & & -0.059 & 0.038 & \\
\hline \multicolumn{5}{|c|}{ Resources \& Infrastructure Interactions } \\
\hline Advertising $^{\mathrm{b}}$ & & -0.326 & 0.141 & $*$ \\
\hline Product Innovation $^{\mathrm{b}}$ & & 0.463 & 1.531 & \\
\hline Display $^{\mathrm{b}}$ & & -0.112 & 0.396 & \\
\hline Distribution $^{\mathrm{b}}$ & & -0.642 & 0.219 & $* *$ \\
\hline Price & & -0.014 & 0.005 & $* *$ \\
\hline \multicolumn{5}{|c|}{ Sociopolitical Governance Interactions } \\
\hline Advertising & & -0.001 & 0.001 & \\
\hline Product Innovation & & 0.009 & 0.005 & $\dagger$ \\
\hline Display & & 0.004 & 0.002 & $\dagger$ \\
\hline Distribution & & 0.001 & 0.000 & $\dagger$ \\
\hline Price & & 0.017 & 0.004 & $* * *$ \\
\hline
\end{tabular}

\begin{tabular}{lc}
\hline Number of groups (emerging vs. developed) & 2 \\
\hline Number of countries (\# of brands) & $14(104)$ \\
\hline$* * * \mathrm{p}<0.001,{ }^{* *} \mathrm{p}<0.01,{ }^{*} \mathrm{p}<0.05, \uparrow \mathrm{p}<0.1$ &
\end{tabular}

a Time dummies variables' coefficient estimates are excluded for ease of presentation.

${ }^{b}$ The coefficient estimates of these variables are multiplied by $10^{3}$ for ease of exposition. 
Table 7 Summary of dominant causal mechanisms

\begin{tabular}{|c|c|c|c|}
\hline $\begin{array}{l}\text { Country-Market } \\
\text { Characteristic }\end{array}$ & $\begin{array}{l}\text { Marketing Mix } \\
\text { Variable }\end{array}$ & $\begin{array}{c}\text { Impact on Marketing } \\
\text { Mix Element's } \\
\text { Influence on } \\
\text { Brand Sales } \\
\end{array}$ & Dominant Mechanism \\
\hline \multirow{4}{*}{$\begin{array}{l}\text { Market } \\
\text { Heterogeneity }\end{array}$} & Product Innovation & Amplifies & $\begin{array}{c}\text { Better marketing mix strategy } \\
\text { design and implementation }\end{array}$ \\
\hline & Display & Amplifies & $\begin{array}{l}\text { Better marketing mix strategy } \\
\text { design and implementation }\end{array}$ \\
\hline & Distribution & Amplifies & $\begin{array}{l}\text { Better marketing mix strategy } \\
\text { design and implementation }\end{array}$ \\
\hline & Price & Amplifies & $\begin{array}{l}\text { Less consumer spending on } \\
\text { branded products }\end{array}$ \\
\hline \multirow{2}{*}{$\begin{array}{l}\text { Unbranded } \\
\text { Competition }\end{array}$} & Product Innovation & Amplifies & Lower branded competition \\
\hline & Distribution & Mitigates & $\begin{array}{l}\text { Less consumer spending on } \\
\text { branded products }\end{array}$ \\
\hline \multirow{3}{*}{$\begin{array}{l}\text { Resources and } \\
\text { Infrastructure }\end{array}$} & Advertising & Mitigates & Higher branded competition \\
\hline & Distribution & Mitigates & Higher branded competition \\
\hline & Price & Mitigates & Higher branded competition \\
\hline \multirow{4}{*}{$\begin{array}{l}\text { Sociopolitical } \\
\text { Governance }\end{array}$} & Product Innovation & Amplifies & $\begin{array}{l}\text { More consumer spending on } \\
\text { branded products }\end{array}$ \\
\hline & Display & Amplifies & $\begin{array}{l}\text { More consumer spending on } \\
\text { branded products }\end{array}$ \\
\hline & Distribution & Amplifies & $\begin{array}{l}\text { More consumer spending on } \\
\text { branded products }\end{array}$ \\
\hline & Price & Mitigates & $\begin{array}{l}\text { More consumer spending on } \\
\text { branded products }\end{array}$ \\
\hline
\end{tabular}


Table 8 Country-market characteristic elasticities of brand sales

\begin{tabular}{lc}
\hline Country-Market Characteristic & Elasticity \\
\hline Market Heterogeneity & -0.45 \\
Unbranded Competition & -0.02 \\
Resources \& Infrastructure & 0.15 \\
Sociopolitical Governance & 1.15 \\
\hline
\end{tabular}

Table 9 Marketing mix elasticities of brand sales

\begin{tabular}{lccc}
\hline & $\begin{array}{c}\text { Full } \\
\text { Sample }\end{array}$ & $\begin{array}{c}\text { Emerging } \\
\text { Markets }\end{array}$ & $\begin{array}{c}\text { Developed } \\
\text { Markets }\end{array}$ \\
\hline Advertising & 0.057 & 0.112 & 0.021 \\
Product Innovation & 0.002 & 0.0045 & 0.0002 \\
Display & 0.115 & 0.070 & 0.144 \\
Distribution & 0.971 & 1.5311 & 0.601 \\
Price & -0.894 & -0.670 & -1.042 \\
\hline
\end{tabular}


Figure 1 Comparison of Emerging and Developed Countries on the Contingency Factors

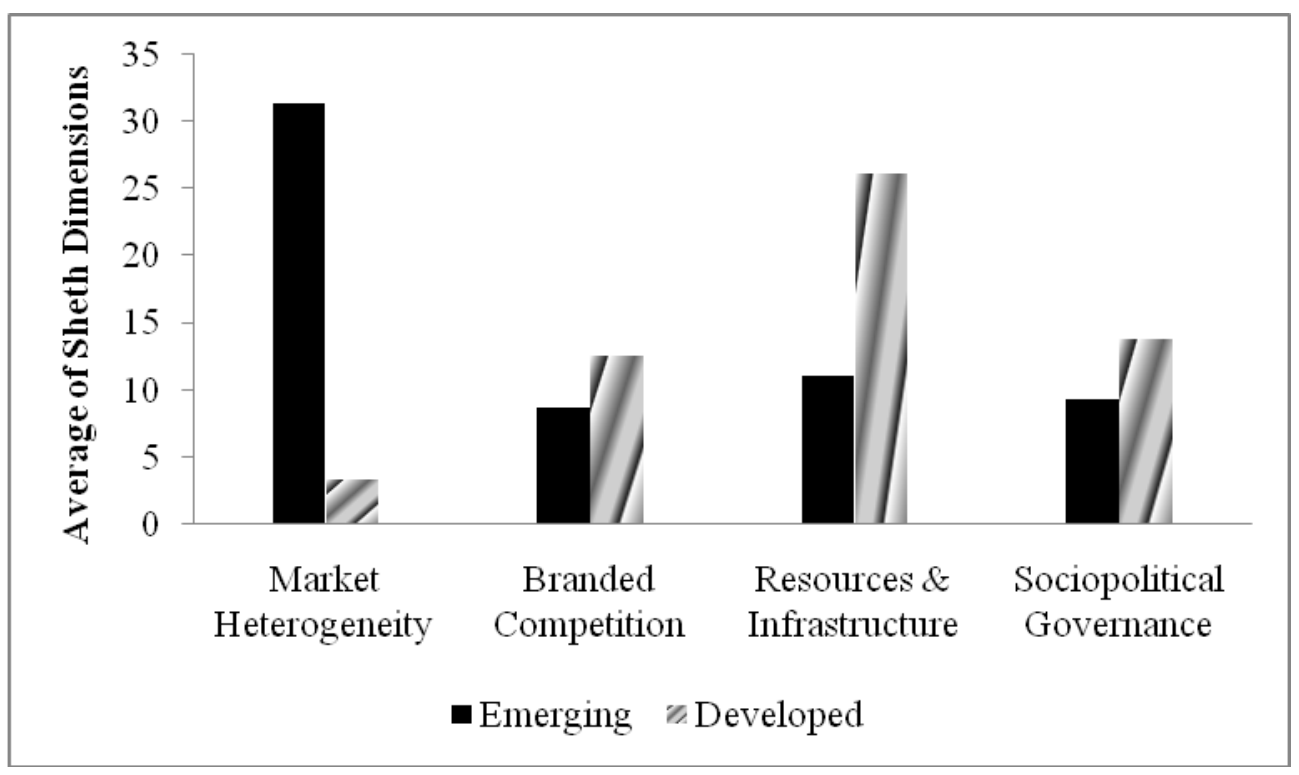


Figure 2 Positioning of the study in international business and marketing strategy literatures*

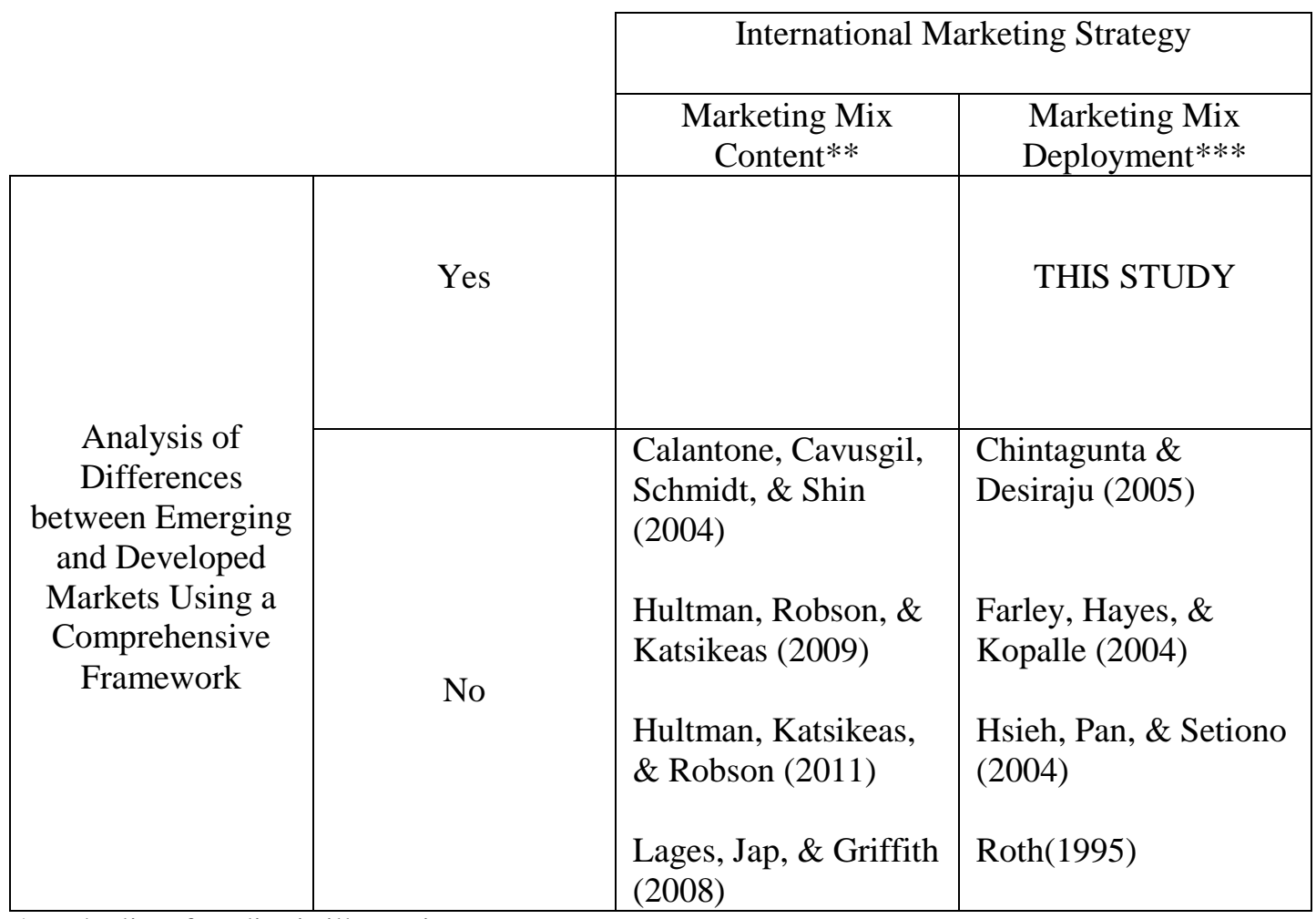

* The list of studies is illustrative.

** Marketing mix content refers to the issues of management of the content of a marketing mix element. For example, the researchers are interested in questions such as "Should the marketing channel format be standardized across country-markets?"

***Marketing mix deployment content refers to the issues of management of the spending associated with a marketing mix element. For example, the researchers are interested in questions such as "Does the effectiveness of distribution intensity change across country-markets?" 
Figure 3 Motivation-ability conceptual framework

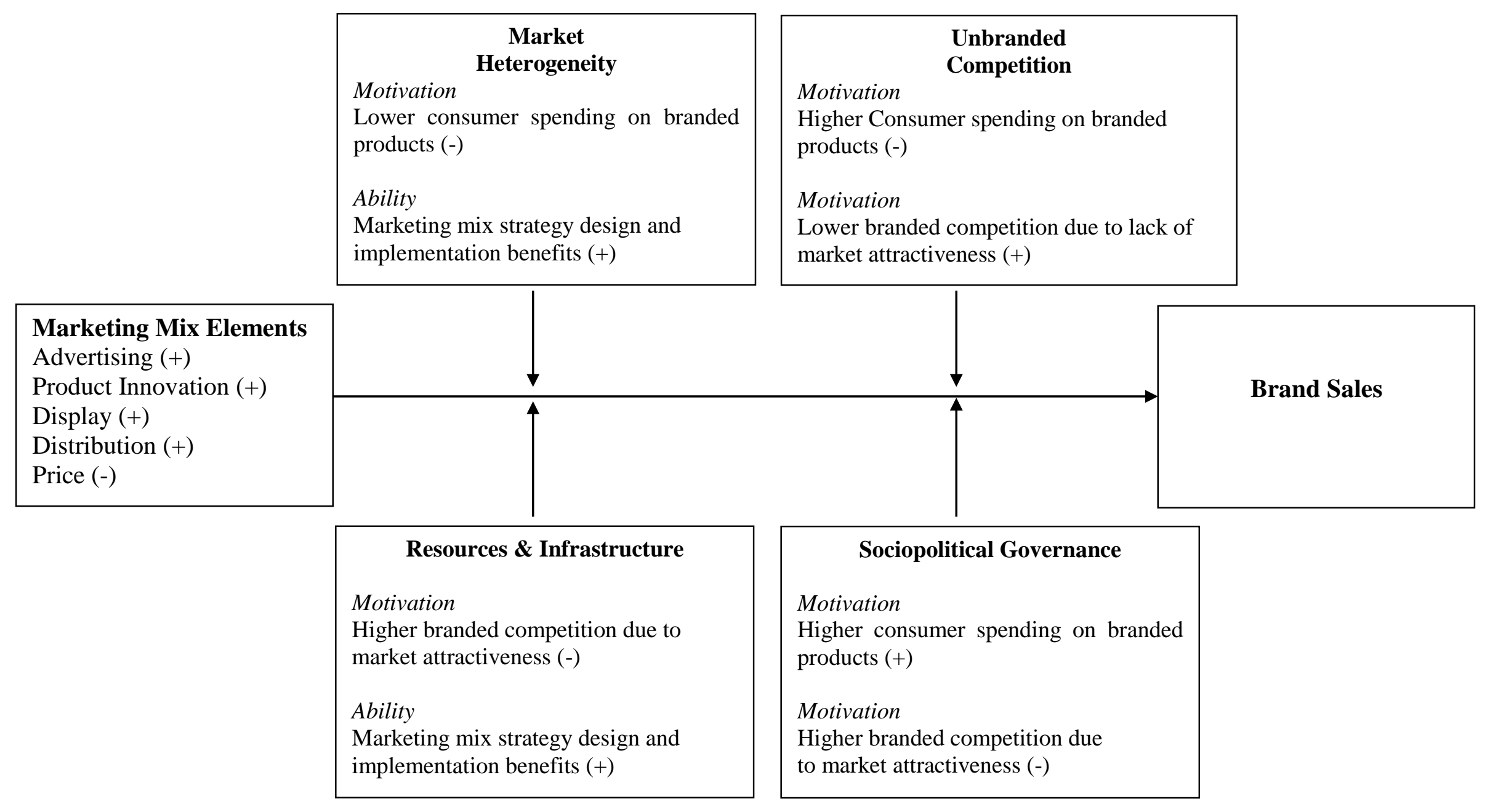


Figure 4 Advertising and resources and infrastructure

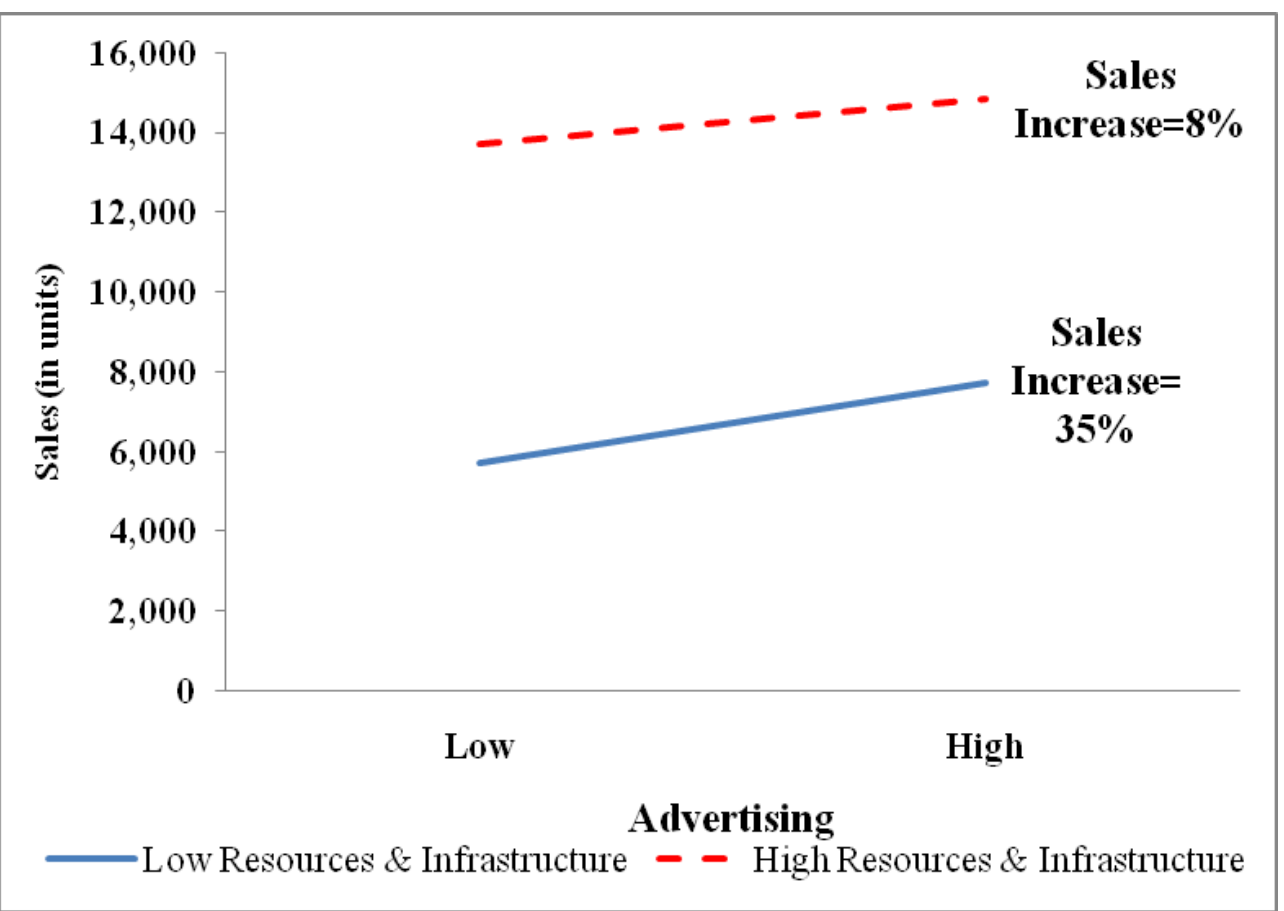

Figure 5 Distribution and resources and infrastructure

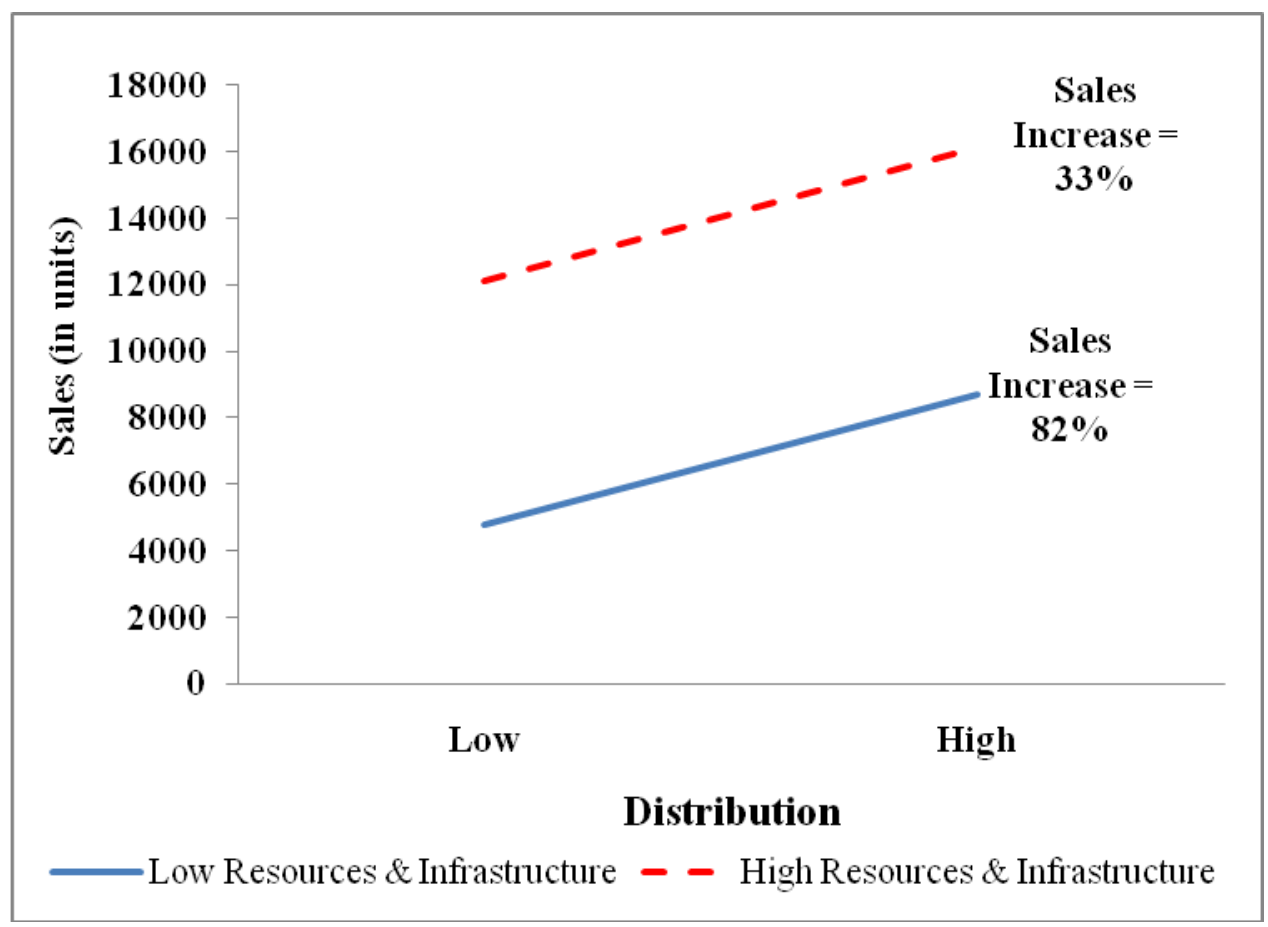

